NBER WORKING PAPER SERIES

\title{
THE CASE OF THE MISSING PRODUCTIVITY GROWTH: OR, DOES INFORMATION TECHNOLOGY EXPLAIN WHY PRODUCTIVITY ACCELERATED IN THE UNITED STATES BUT NOT THE UNITED KINGDOM?
}

\author{
Susanto Basu \\ John G. Fernald \\ Nicholas Oulton \\ Sylaja Srinivasan \\ Working Paper 10010 \\ http://www.nber.org/papers/w10010 \\ NATIONAL BUREAU OF ECONOMIC RESEARCH \\ 1050 Massachusetts Avenue \\ Cambridge, MA 02138 \\ October 2003
}

Forthcoming in the NBER Macroeconomics Annual 2003. We thank Olivier Blanchard, Ian Bond, Jeff Campbell, Mark Gertler, Elhanan Helpman, Dale Jorgenson, John Laitner, Jim Morsink, John Nichols, Ken Rogoff, Bob Triest, Gianluca Violante, and Christina Wang for helpful comments and discussions. We thank Shanthi Ramnath and Sunil Kapadia for superb research assistance. The views expressed in this paper are those of the authors and do not necessarily represent the views of others affiliated with the Federal Reserve System or the Bank of England. The views expressed herein are those of the authors and are not necessarily those of the National Bureau of Economic Research.

(C)2003 by Susanto Basu, John G. Fernald, Nicholas Oulton, and Sylaja Srinivasan. All rights reserved. Short sections of text, not to exceed two paragraphs, may be quoted without explicit permission provided that full credit, including (C) notice, is given to the source. 
The Case of the Missing Productivity Growth: Or, Does Information Technology Explain why Productivity Accelerated in the United States but not the United Kingdom?

Susanto Basu, John G. Fernald, Nicholas Oulton, and Sylaja Srinivasan

NBER Working Paper No. 10010

October 2003

JEL No. E22, O47, O52

\section{$\underline{\text { ABSTRACT }}$}

We argue that unmeasured investments in intangible organizational capital — associated with the role of information and communications technology (ICT) as a 'general purpose technology' — can explain the divergent U.S. and U.K. TFP performance after 1995. GPT stories suggest that measured TFP should rise in ICT-using sectors, perhaps with long lags. Contemporaneously, investments in ICT may in fact be associated with lower TFP as resources are diverted to reorganization and learning. In both the U.S. and U.K., we find a strong correlation between ICT use and industry TFP growth. The U.S. results, in particular, are consistent with GPT stories: the TFP acceleration was located primarily in ICT-using industries and is positively correlated with industry ICT capital growth from the 1980s and early 1990s. Indeed, as GPT stories suggest, controlling for past ICT growth, industry TFP growth appears negatively correlated with increases in ICT capital services in the late 1990s. A somewhat different picture emerges for the U.K. TFP growth does not appear correlated with lagged ICT capital growth. But TFP growth in the late 1990s is strongly and positively associated with the growth of ICT capital services, while being strongly and negatively associated with the growth of ICT investment.

Susanto Basu

Department of Economics

University of Michigan

Ann Arbor, MI 48109-1220

and NBER

sbasu@umich.edu

John G. Fernald

Research Department, $11^{\text {th }}$ Floor

Federal Reserve Bank of Chicago

230 LaSalle Street

Chicago, IL 60604

jfernald@frbchi.org
Nicholas Oulton

Centre for Economic Performance, London School of Economics and Political Science

Houghton Street

London WC2A 2AE

n.oulton@1se.ac.uk

Sylaja Srinivasan

Structural Economic Analysis Division

Monetary Analysis, HO-2

Bank of England

Threadneedle Street

London EC2R 8AH

sally.srinivasan@bankofengland.co.uk 


\section{Introduction}

After the mid-1990s, labor and total factor productivity (TFP) accelerated in the United States but not in most other major economies. A growing body of research has explored the robustness of the U.S. acceleration, generally concluding that the acceleration reflects an underlying technology acceleration. This research, along with considerable anecdotal and microeconomic evidence, suggests a substantial role for information and communications technology (ICT). ${ }^{1}$

In this paper, we seek fresh insights into the nature of the U.S. experience in international comparative perspective. First, we focus narrowly but more deeply on the relative productivity performance of the United States and the United Kingdom. Second, to better understand comparative productivity performance, we do detailed growth accounting at an industry level for both countries. Third, we focus on the role of ICT, which many see at the heart of the productivity acceleration.

Why do we take this approach? First, the U.K. experience provides an intriguing counterpoint to both the U.S. and Continental European experiences. In particular, overall macroeconomic performance looks similar to that of the United States, but productivity performance looks similar to the rest of Europe.

In terms of late 1990s macro performance, output growth in both the U.S. and U.K. rose, investment surged, inflation moderated, and unemployment rates fell to levels that seemed implausible just a few years earlier. In the U.S. case, many commentators attributed this strong macroeconomic performance to the strong productivity growth. But in the U.K., both labor and total factor productivity growth decelerated rather than accelerated. Hence, understanding the U.K. experience may provide insights into the U.S. experience.

In terms of cross-country productivity evidence, van Ark et al. (2002) and Gust and Marquez (2002), among others, document that TFP and labor productivity growth decelerated in the European Union overall and in Japan. ${ }^{2}$ To the extent that one expects ideas—especially when embedded in easily traded physical capital—to diffuse easily across borders, the lack of a strong response abroad surprised many observers. Hence, understanding the lack of a productivity acceleration in the United Kingdom may provide insight into the anemic productivity performance elsewhere.

\footnotetext{
${ }^{1}$ See Jorgenson (2001) or Jorgenson, Ho, and Stiroh (2002) for reviews of the empirical literature on the productivity acceleration and the role of information technology. We discuss this literature in greater detail later.

${ }^{2}$ Gust and Marquez look at 13 industrialized countries. Compared with the 1980-95 period, their data show a positive TFP acceleration in 1995-2000 for the United States, Finland, Sweden, Australia, and Canada.
} 
Second, we build up from industry data in order to understand the aggregate data. Because of data limitations, most cross-country comparisons have used aggregate data. But many hypotheses about relative productivity growth—e.g., about the role of ICT—are observationally equivalent in aggregate data.

In order to implement this bottom-up approach, we construct a new industry-level dataset for the United Kingdom that includes industry use of information technology. This allows us to isolate the sources of U.S. and U.K. productivity growth at an industry level.

Third, we seek to better understand the myriad roles of ICT in both countries. Much of the existing discussion has focused on the distinction between the use and production of ICT. In standard neoclassical growth accounting, the use of ICT leads to capital deepening, which boosts labor productivity. TFP growth in producing ICT goods shows up directly in the economy's measured TFP.

This standard growth accounting framework leads to the first question we ask of the data, for both the United States and the United Kingdom: Were the 1990s a time of rising total factor productivity growth outside of the production of ICT? Although existing work often seems to consider this an open question, our industry data strongly support the view that a majority of the TFP acceleration reflects an acceleration outside of the production of ICT goods and software. ${ }^{3}$ Even when we focus on arguably “well-measured” sectors (Griliches 1994; Nordhaus 2002), we find a substantial TFP acceleration outside of ICT production.

The productivity acceleration in sectors that use ICT raises the deeper question: Does ICT itself explain some or all of the measured acceleration in TFP in sectors using it? This question is at the heart of the debate over whether computers are a new "General Purpose Technology" (Helpman and Trajtenberg, 1998, for example, argue 'yes'; Gordon, 2003, rejects this notion). The main feature of a GPT is that it leads to fundamental changes in the production process of those using the new invention. Chandler (1977) discusses a number of examples, such as how railroads allowed nationwide catalog sales, which in turn transformed retailing. David and Wright (1999) also discuss historical examples.

Indeed, the availability of cheap ICT capital is likely to effect truly major changes only if firms can, as a result, deploy their other inputs in radically different and productivity-enhancing ways. That is, if cheap computers and telecommunications equipment stimulates an ever-growing series of complementary inventions

\footnotetext{
${ }^{3}$ In our view, more studies than not find a widespread acceleration in technology, e.g., Basu, Fernald, and Shapiro (2001), Baily and Lawrence (2001), Bosworth and Triplett (2002), Council of Economic Advisers (2003), Jorgenson,
} 
in industries using ICT, thereby continually shifting out the demand curve for ICT capital, then innovations in the production of ICT can have substantial long-run effects before diminishing returns set in.

Why do we focus so intently on relatively subtle arguments about the role of ICT? An important reason is that other explanations for the U.K. experience fall short. In particular, in this case of the missing productivity growth, we round up and interrogate the plausible suspects. Some are routine and can be dismissed quickly; others require deeper investigation, as the paper discusses. The suspects include the following:

(1) Cyclical mismeasurement of inputs. Productivity is generally procyclical, rising sharply in the early phase of a business cycle upswing. Basu, Fernald, and Shapiro (2001) and Council of Economic Advisers (2003), using different methods, conclude that the level of unobserved labor effort and capital utilization probably fell in the U.S. after the mid-1990s. For example, both capacity utilization and hours per worker fell over the second half of the 1990s. In the U.K. case, macro performance was stronger in the second half of the 1990s than the first, making it unlikely that business-cycle considerations held down measured productivity.

(2) Differences in national accounts methodology. The U.S. employs hedonic methods for some crucial ICT price indices (e.g., for computers), while the U.K. and many other countries do not. Also, the U.K. has only recently included software as a form of investment in GDP. Is it possible that part of the difference between U.S. and U.K. performance is a statistical illusion? The data we use for the U.K. addresses this issue by using U.S. methodologies.

(3) Differences in regulation of product and labor markets. Many people suggest that inflexible labor and product markets prevent European countries from benefiting from new technologies and innovations. Gust and Marquez (2002), for example, find that countries with a more burdensome regulatory environment - particularly regulations affecting labor market practices-tended to adopt information technologies more slowly and also had slower total factor productivity growth. Gust and Marquez suggest that economies with more flexible labor and product markets should benefit first, and to a larger extent, than less flexible economies.

But many of the institutional features-such as the extent of the labor and product market rigidities emphasized by Gust and Marquez — are similar in the United Kingdom and the United States. Thus, this suspect seems completely absent from the scene.

(4) U.K. unemployment fell sharply. When unemployment falls, low-skilled workers are often the ones drawn disproportionately into the labor force, reducing measured labor and total factor productivity. We control for labor quality, but the productivity puzzle remains.

(5) Differences in the size of the high-TFP-growth ICT-producing sectors. If the ICT sector were larger in the U.S., this could explain some at least of the aggregate gap in productivity growth. But relative to GDP, the ICT-producing sectors are about the same size in the two countries (Oulton, 2001b). And even when outside of ICT production, the U.S. data still show a sharp productivity acceleration, whereas the U.K. data show an even sharper deceleration.

Stiroh, and Ho (2002), Nordhaus (2002), Oliner and Sichel (2000), Stiroh (2002a, 2002b). Gordon (2003) remains a skeptic. 
(6) Intensity of competition. Although measures of regulation look similar across sectors, some commentators think that many sectors of the U.K. economy have less competitive pressure, and that this retards pressure for innovation. (See Nickell 1996, Lovegrove, et al. 1999.) ${ }^{4}$

(7) Disruption costs associated with investment. Investment accelerated in both the U.S. and U.K. data in the second half of the 1990s. A long literature suggests that because of various adjustment costs, measured output and productivity are lower in the period in which the investment takes place. Basu, Fernald, and Shapiro (2001) argue that in the second half of 1990s, considerations of adjustment costs raise the magnitude of the U.S. acceleration in "true" technology relative to measured productivity; a similar calibration reduces the magnitude of the slowdown in U.K. productivity growth. But such calibrations don't resolve the puzzle, in part because they increase the acceleration in U.S. productivity at the same time.

(8) Finally, the GPT nature of ICT capital: Benefiting from ICT requires substantial complementary investments in learning, reorganization, and the like, so that the payoff in terms of measured output may be long delayed. This is our main hypothesis. As it turns out, the evidence is much stronger for the U.S. than for the U.K., where the evidence remains mixed. Much of the evidence for this hypothesis is circumstantial-the suspect's fingerprints are all over the crime scene.

What is the evidence for the GPT hypothesis? To begin, once we have confirmed that measured U.S.

TFP accelerated strongly in non-ICT-producing industries during the late 1990s, we assess whether the acceleration in measured TFP is related to the use of ICT. We find that the U.S. results are quite supportive of the joint hypothesis that ICT is a GPT-i.e., that complementary investment is important for realizing the productivity benefits of ICT investment—and that, since these complementary investments are unmeasured, they can help explain the cross-industry and aggregate TFP growth experience of the U.S. in the 1990s. Specifically, we find that industries that had high ICT capital growth rates in the 1980s or early 1990s (weighted by ICT revenue shares, as suggested by theory) also had high TFP growth rates in the late 1990s. Controlling for lagged capital growth, however, ICT capital growth in the late 1990s was negatively correlated with contemporaneous TFP growth. These results are consistent with-indeed, predicted by-a simple model of unmeasured complementary capital investment.

Bolstered by these encouraging results for the U.S., we ask whether complementary capital accumulation can explain the "missing" TFP growth in the U.K. in the second half of the 1990s. The aggregate data are encouraging: the U.K. had a huge ICT investment boom in the late 1990s—by some measures, a larger boom than the one labeled historic in the U.S. over the same period. The U.K. had had much lower ICT investment in the early 1990s, due to a severe recession. And the U.S. results say that current TFP growth is

\footnotetext{
${ }^{4}$ A long literature has, of course, explored how competition affects innovation. Aghion et al (2002) provide recent theoretical and empirical work suggesting that over some range, greater competition raises innovation.
} 
positively correlated with lagged investment, but negatively correlated with current investment—and on both counts measured U.K. TFP growth should have been low in the late 1990s.

However, results using industry-level U.K. data are more mixed. TFP growth does not appear correlated with lagged ICT capital growth, which could reflect that lagged ICT capital growth is a poor proxy for unobserved U.K. complementary capital accumulation. Contemporaneously, rising ICT capital growth is positively, not negatively, correlated with the industry's TFP acceleration, although ICT investment growth (as the proxy for unobserved complementary investment) is negatively correlated. If the lags between ICT investment and unobserved complementary investment are shorter in the U.K., then this finding, too, is consistent with the GPT story. However, the magnitude of the negative investment effect is too small to explain the pervasive TFP slowdown in U.K. industries. On the other hand, our results do suggest, albeit tentatively, that the U.K. could see an acceleration in TFP growth over the next decade.

In sum, we search for suspects in this case of the missing U.K. productivity growth. The crime is of particular interest because the most obvious suspect—differences in labor and product market regulationsappears to be absent from the scene. In our search for clues, we ask what sectors account for the productivity acceleration in the U.S. data, and explore whether those same sectors show an acceleration in the U.K. We explore the role of ICT in the U.S. and U.K.

Although our tentative and incomplete answer to the puzzle emphasizes explanation eight - the GPT nature of ICT, and the different timing of U.S. and U.K. investment in ICT-more than one of the suspects may have conspired in the crime. For example, our explanation takes as given U.K. complementary investment and leaves open the question of why the timing differs. Other suspects may have greater guilt in that question.

The organization of the paper is as follows. Section 2 compares recent U.S. and U.K. macroeconomic experience and makes some broader observations on the U.S. versus European experiences. Section 3 presents data and basic TFP results, and also discusses some augmented growth accounting. Section 4 focuses more specifically on the potential role of information technology as a GPT. Section 5 provides empirical evidence on the importance of ICT in the U.S. and U.K., and provides some preliminary empirical results suggesting that the GPT story fits at least some of the facts. Section 6 concludes. 


\section{Comparative U.S., U.K., and Continental European Macroeconomic Performance}

\section{$2.1 \quad$ UNITED STATES AND UNITED KINGDOM}

The U.S. economy performed admirably in many dimensions in the late 1990s. As Table 1 shows, output growth rose, investment surged, inflation moderated, and unemployment rates fell to levels that seemed implausible just a few years earlier. Many commentators attributed this macroeconomic strength to rapid productivity growth—-linked particularly to information technology—which rose at a rate nearly double that of the preceding years. For example, the 2001 Economic Report of the President (page 245) stated that:

The economy this expansion has created is not just greater in sheer size but 'new' in its structure and performance. It is dramatically more information intensive and more technology driven, more productive and more innovative. Today's economy utilizes new, more efficient business practices and has redefined many traditional relationships between suppliers, manufacturers, investors, and customers to achieve ever-greater efficiency. The cumulative result of these trends and their interactions is a New Economy, one that is currently providing Americans of all walks of life the benefits of high growth, low inflation, high productivity, rising incomes, and low unemployment.

As Table 1 shows, however, the United Kingdom shared many of these desirable macroeconomic features. Output rose more quickly than in the preceding period; investment boomed; unemployment rates fell sharply; inflation moderated. But in the United Kingdom, productivity growth does not appear to be the explanation for this strong macroeconomic performance. Both labor and total factor productivity grew more slowly in the second half of the 1990s than in the first half.

\subsection{BROADER REFLECTIONS ON EUROPEAN CONVERGENCE AND DIVERGENCE}

van Ark et al. (2002) provide a fairly comprehensive comparison of the European Union (EU) and the

United States, using aggregate national accounts data. Their results cover 12 of the 15 EU countries, comprising 95 percent of EU GDP in 2000 (Belgium, Luxembourg and Greece are excluded), for 1980-2000. They find that labour and total factor productivity grew much faster in the EU than in the United States in the 1980s and first half of the 1990s. Labor productivity rose by nearly 2-1/2 percent per year, about 1-1/4 percentage points faster than in the United States. But in the second half of the 1990s, productivity decelerated in Europe while the opposite occurred in the U.S. As a result, in 1995-2000, labor productivity grew about 3/4 percentage points per year faster in the United States than in the E.U.

With more detailed growth accounting, van Ark et al. find that some of this U.S advantage reflected the higher contribution to labor productivity from ICT use, and some reflected a larger contribution of ICT 
production to TFP growth. But another important factor was that TFP growth in the non-ICT part of the economy fell sharply in Europe but rose in the United States. As we shall see, our consideration of the U.K. and U.S. shows the same picture.

The recent divergence reflects a reversal in convergence forces. Until the 1990s, labor productivity generally grew more rapidly in Europe than in the U.S. The reason seemed clear: The European productivity level was lower, so the Europeans were catching up. Table 2 shows that in 1999, the level of labor productivity in the market sector of the U.K. lagged France and Germany as well as the United States. In particular, the U.S. led the U.K. by 39 percent, France by 22 percent and Germany by 19 percent:

\section{TABLE 2}

\section{LABOR PRODUCTIVITY IN THE MARKET SECTOR 1999, U.K. = 100}

\begin{tabular}{|l|l|}
\hline United States & 139 \\
\hline France & 122 \\
\hline Germany & 119 \\
\hline United Kingdom & 100 \\
\hline
\end{tabular}

Note: Market sector is GDP, excluding public administration and defense, health, housing, and education, per hour worked, measured at purchasing power parities.

Source: O’Mahony and de Boer (2002, Table 7).

Intuitively, it is easier to grow when all you have to do is copy a successful example. And the neoclassical growth model predicts that countries with a lower level of capital will grow faster along the transition path. From this perspective, it was a surprise when the productivity gap between the United States and Europe started to widen again from around 1995.

Many popular accounts stress the U.S. strength in basic science and technological innovation. In addition, a vibrant venture capital industry is ever eager to commercialise the results of the latest research. Hence, one popular interpretation of the productivity acceleration is that the U.S. benefited from rapid leadingedge creation of knowledge in producing high-tech goods; other industries then benefited from the presumed relatively costless adoption of these new technologies, i.e., by capital deepening.

Such an account is not altogether compelling. First, some of the basic technological innovations were, in fact, European in origin. For example, if any one person can be said to have invented the World Wide Web, that person was not Al Gore but an Englishman, Tim Berners-Lee. In the 1980s, Berners-Lee created the essential 
elements of the Web — URLs, HTML, the HTTP protocol, web browser and web server programs—while employed at CERN, the European center for research in particle physics. ${ }^{5}$

Second, if the difference were just science and basic innovation, with technology adoption by other sectors, one could reasonably expect the revival to diffuse relatively quickly—e.g., PCs and other new technologies developed in the United States could be quickly installed in Europe as well. In other words, if the issue were simply that the ideas were initially developed and implemented in the United States, then the European failure to experience a comparable revival would be particularly puzzling.

Third, as we discuss in Section 3, much of the measured productivity acceleration reflects an acceleration in TFP in sectors other than those producing ICT. So the U.S. story goes beyond simple capitaldeepening, which in principle could be easily replicated elsewhere.

If the U.S. advantage is not simply its capability in basic science and technological innovation, then what is it? As we discuss later, many stories of the benefits of ICT emphasize that adopting new technologies requires substantial complementary investments (such as reorganizations) and co-inventions. Gust and Marquez (2002), following Greenspan (2000) and Feldstein (2001), promote essentially this story in arguing that labor and product market regulations prevent many countries in Europe from benefiting fully from new technologies because the regulations inhibit necessary reorganizations.

\subsection{STRUCTURAL REFORM IN THE UNITED KINGDOM}

If the U.K has not yet benefited from ICT to the same extent as the U.S, it is not because of inflexible labor markets, burdensome regulation, or the dead hand of government control of industry — all those things summed up under the label "Eurosclerosis." The U.K. now ranks highly on measures of competitiveness, labor market flexibility, ease of starting a business and freedom from burdensome regulations; in all these areas, Card and Freeman (2001) argue that the U.K.'s rank is similar to, and sometimes superior to, that of the United States.

Why does the U.K. appear to have a more flexible economy than does continental Europe? The rise of Margaret Thatcher to power in 1979 set in motion an extensive program of structural reform. This program continued under her Conservative successor, John Major, Prime Minister from 1990 to 1997. The elements of

\footnotetext{
${ }^{5}$ See Berners-Lee (1999). Of course, the Web relies on the Internet, which provides the physical infrastructure and low-level software protocols like TCP/IP. In the 1970s, the U.S. Defense Department funded the Internet, and initially commercial use of it was banned. But the government did not claim ownership of the intellectual property and it permitted key personnel to quit and set up companies to exploit the new technology (Abbade 1999).
} 
reform most relevant in the present context were fivefold. First, the government abandoned the attempt to control inflation through wage and price controls; these had been employed in increasingly restrictive form since the 1950s but had become particularly important in the aftermath of the first oil shock in 1973. Second, it reduced the legal privileges of the trade unions (e.g., secondary picketing was banned), while also increasing the rights of individual members vis-à-vis their own union (e.g., requiring ballots before strikes could be called). Third, it began privatizing the "commanding heights" of the British economy-steel, telecommunications, and later on the utilities (gas, electricity and water supply), coal mining, and the railways. Where elements of natural monopoly existed as in telecommunications and the utilities, independent regulators were set up. Fourth, it announced that it would cease to "bale out lame ducks": no company was now "too important to fail." This new policy was largely adhered to and was cemented by selling off commercial companies that had for various reasons fallen into government ownership (e.g., Rolls Royce, British Aerospace, British Airways and the U.K.'s national champion in the car industry, then known as British Leyland). Fifth, financial markets were deregulated and virtually all exchange controls were abolished.

The Labour government that came to power in 1997 announced in advance that it did not intend to reverse the reforms of the Thatcher-Major period. It has continued the process of privatization. For example, air traffic control services are now supplied by a private company, not a government agency as in the United States. Immediately after it came to power, the new government gave the Bank of England operational independence in monetary policy. A Monetary Policy Committee was established at the Bank with the remit of meeting a target for inflation set by the Chancellor of the Exchequer: this target was (and has continued to be) 2.5 percent p.a. as measured by the Retail Prices Index excluding mortgage interest payments (RPIX). The new government also announced a framework of rules for fiscal policy.

Apart from law and order and defense, the government owns or directly controls little of the economy other than health and education. In 1999, less than 30 percent of the labor force were members of a trade union, down from 50 percent in 1980; collective bargaining agreements now cover fewer than 36 percent of the labor force, down from 68 percent, over the same period (Nickell and Quintini, 2001). The bulk of union members work in the public sector; as in the U.S., private sector union membership is now quite low. The kind of regulation found in some European countries, which make it costly to close plants, does not exist in the U.K. 
In sum, as Card and Freeman (2001) argue, the U.K.'s reform program has reversed the process of relative economic decline that became apparent in the 1960s and 1970s. ${ }^{6}$ Nor does weak U.K. productivity performance reflect a failure of macroeconomic policy. Inflation peaked at an annual rate of about 9-1/2 percent in late 1990 but then declined steadily towards what became the target rate of 2.5 percent in mid 1997; since then, inflation has fluctuated in a narrow range. The unemployment rate (the internationally comparable ILO definition) peaked in early 1993 at 10.7 percent. Since then it has halved.

Lest this should seem to paint too rosy a picture, one long-standing weakness continues to hamper the U.K. economy: a low level of skills. In 1999, the share of the U.K. labor force with a degree or higher was little more than half the U.S. share. Although the U.K. share was similar to France and Germany, the U.K. proportion with vocational qualifications was also much lower:

\section{TABLE 3}

LABOR FORCE SKILLS, 1999

\begin{tabular}{lccc}
\hline $\begin{array}{l}\text { Percentages at } \\
\text { different levels }\end{array}$ & $\begin{array}{l}\text { Higher: Degree level } \\
\text { or higher }\end{array}$ & $\begin{array}{l}\text { Intermediate: Post-high-school } \\
\text { vocational qualifications }\end{array}$ & $\begin{array}{l}\text { Low: High school } \\
\text { only or below }\end{array}$ \\
\hline United States & 27.7 & 18.6 & 53.7 \\
France & 16.4 & 51.2 & 32.4 \\
Germany & 15.0 & 65.0 & 20.0 \\
United Kingdom & 15.4 & 27.7 & 56.9 \\
\hline
\end{tabular}

Source: O’Mahony and de Boer (2002, Table 5).

Other aspects of policy may also be relevant. For example, some have argued that U.K. town and country planning laws limit the expansion of new forms of retailing (Lovegrove et al.1999). More generally, Nickell (1996) argues that competition promotes productivity growth. But historically, U.K. law has been much more lenient towards uncompetitive behavior than has been the case in the U.S. (This may now be changing with the coming into force in 2000 of the 1998 Competition Act.)

\section{Data and preliminary empirical results}

We begin with results from standard growth accounting in order to establish some stylized facts. Doing so will help us dismiss a few potential explanations for the productivity divergence and, hence, helps motivate our later focus on the general-purpose nature of ICT.

\footnotetext{
${ }^{6}$ The underlying weaknesses of the U.K. economy and the extent to which these have been alleviated by policy are discussed in Bean and Crafts (1996), Oulton (1995) and Crafts and O’Mahony (2001). O'Mahony and de Boer (2002) compare productivity levels and growth rates across countries.
} 
We focus on disaggregated, industry level results for total factor productivity. Even if one is interested in aggregate outcomes, such a disaggregated approach is helpful. Any number of stories can be told to explain a single time series like GDP or GDP per worker. It is often very difficult to reject a particular hypothesis using just aggregate data. Here sectoral and industry data can help. In addition, if one wishes to explore the differences between the ICT-producing and ICT-using sectors, then it is natural to disaggregate.

In this section, we first briefly describe our data sets; we then discuss results. Finally, we consider and reject several sources of measurement error as explanations for our results.

\section{$3.1 \quad$ U.S. DATA}

We use a 51-industry dataset that updates that used in Bosworth and Triplett (2002) and Basu, Fernald, and Shapiro (2001). For industry gross output and intermediate-input use, we use industry-level national accounts data from the Bureau of Economic Analysis. For capital input—including detailed ICT data—we use Bureau of Labor Statistics capital input data by disaggregated industry. For labor input, we use unpublished BLS data on hours worked by two-digit industry. Gross output is not available before 1977, and, for some industries, is not available before 1987..$^{7,8}$

There are several issues to keep in mind. First, we do not have industry measures of labor quality, only raw hours. We do incorporate an aggregate adjustment for labor quality in our 'top line' numbers, using an index calculated by Aaronson and Sullivan (2001) (their index is relatively close to that produced by the BLS). Second, the BEA industry data come from the income-side of the national accounts which, as is well known, accelerated faster than the expenditure side in the late 1990s. It is not clear which side of the national accounts is more reliable; the Council of Economic Advisers, for example, takes an agnostic view and uses a geometric average for growth accounting. This is not possible with industry-level data.

\footnotetext{
${ }^{7}$ We thank Jack Triplett for sending us their industry dataset that merged the BEA and BLS data. We updated the BEA data to incorporate November 2002 NIPA industry revisions and also removed owner-occupied housing. The BEA labor compensation data do not include proprietors or the self-employed, so we follow Bosworth and Triplett in using BLS data that correct for this. We thank Larry Rosenblum at the BLS for sending us unpublished industry hours data, which makes adjustments for estimated hours worked by non-production and supervisory employees as well as the self-employed. We updated the BLS capital data from http://www.bls.gov/web/prod3.supp.toc.htm (downloaded December 2002). We follow Bosworth and Triplett and exclude several service sectors where consistent input or output data are unavailable: holding and other investment offices, social services, membership organizations, and other services. We do include those industries in the ICT capital-by-industry data reported later in the paper.

${ }^{8}$ Jorgenson, Ho, and Stiroh (2002) use different industry data sources; unfortunately, their dataset was not publicly available as of April 2003. Brookings Institution (2002) discusses key differences across datasets.
} 
The detailed industry definitions differ a bit from the U.K. To simplify comparisons in summary tables, we aggregate to approximately a 1-digit level, where definitions are reasonably close.

\section{$3.2 \quad$ U.K. DATA}

We use a new industry dataset developed at the Bank of England, containing data for 34 industries spanning the whole U.K. economy, running from 1979 to $2000 .^{9}$ For each industry, we have gross output and inputs of capital services, labor services, and intermediates, in both nominal and real terms. Capital services cover three types of ICT and four types of non-ICT capital. The non-ICT assets are structures, plant and machinery (equipment), vehicles; and intangibles. The three ICT assets are computers, software and communication equipment. The real capital input index is a rental-price weighted average of the growth rates of these asset stocks. The real intermediate index is a weighted average of purchases from all of the other industries and from imports.

Labor services are measured as hours worked and are built up in a number of steps. First, we estimate total usual hours for each industry. Second, we apply two aggregate adjustments. The first is to constrain the growth of total hours to conform with the official index of aggregate hours worked. This allows for cyclical variability in hours, though at the same rate in all industries. The second aggregate adjustment is to apply a correction for changes in labor quality, mainly due to rising levels of educational attainment (quality change is discussed below).

Prior to several adjustments described below, the data set is reasonably consistent with the official U.K. national accounts in both real and nominal terms. This is important because, otherwise, any story based on industry data will not be very convincing as an explanation of what is happening at the macro level.

For making comparisons with the United States, we need to use the same methodology to derive ICT capital services in both countries. We therefore assume that computers and software depreciate geometrically at rates similar to those used in studies of the U.S. (e.g. Jorgenson and Stiroh, 2000), which are in turn based on those used by the Bureau of Economic Analysis (BEA). We also employ U.S. price indices, converted to sterling terms, to deflate investment in current prices. U.S. ICT prices generally fall faster than U.K. ones, so this means that our ICT capital and investment measures will grow more rapidly. The U.K. is also an ICT producer, so we have made corresponding adjustments to the growth rates of output of the ICT industries. 
In addition, we have made a large adjustment to the official nominal level of software investment, multiplying it by a factor of three, for reasons discussed in Oulton (2001b) and (2002). Compared with the United States, official software investment is very low relative to computer investment; also, a much lower proportion of the sales of the computer services industry is classified as investment. The "times three" adjustment can be justified as putting the two countries on the same footing methodologically.

\subsection{EXONERATING TWO OF THE SUSPECTS}

We briefly expand on two broad data issues related to the challenge of cross-country data comparability. First, the official U.K. statistics do not control for hedonics in the same way or degree that the U.S. national accounts do. Second, the U.K. had an even larger decline in unemployment than the United States, which could reduce overall productivity if those pulled into the labor force have lower-than-average skills and productivity. Neither story explains the divergent performance of U.K. and U.S. productivity since, as noted above, our U.K. industry data incorporate adjustments for these two issues.

First, what difference do the computer hedonics make? National accounts in Europe (including the U.K.) have, so far, lagged in introducing satisfactory methods for measuring ICT, leading to implausibly large variation across countries in computer price indices (Schreyer 2002). Indeed, the main weakness of U.S. methods of measuring ICT is that they don't go far enough. For example, there is no true price index for investment in custom and own account software (two thirds of the total), only for prepackaged software (Parker and Grimm, 2000). And within telecommunications, hedonic methods are only just starting to be introduced (Grimm, Moulton, and Wasshausen, 2002).

A related issue is that although measured GDP in both Europe and the U.S. now includes software investment, different methodologies lead to substantial differences in estimated levels (Lequiller, 2001). Hence, again, cross-country comparisons need to use impose a comparable methodology.

Most researchers have dealt with these issues by applying as far as possible U.S. methods to other countries. However, that this will not necessarily transform European productivity performance because inputs as well as output grow faster (see again Schreyer 2002). Oulton (2001b) finds that U.S. methodology raises the

\footnotetext{
${ }^{9}$ A detailed appendix describing the industry input, output, and ICT capital data is available on request.
} 
growth rate of U.K. GDP by about a third of a percentage point per annum in the last half of the 1990s. Despite this, aggregate labor productivity still slowed down over this period. ${ }^{10}$

Second, why isn't declining labor quality quantitatively important in explaining the divergence? We apply an index of U.K. labor quality (constructed by Burriel-Llombart and Jones 2003). As is standard, we define labor quality as the growth of quality-adjusted labor input minus the growth of unweighted total hours. ${ }^{11}$ The unemployed do tend to have below-average skills or qualifications and, indeed, falling unemployment contributed to a lower growth rate of labor quality from the first to second half of the 1990s. But other factors affected U.K. labor quality, such as increasing female participation, declining participation by older, unskilled men, and (of particular importance) the retirement or death of older, less qualified people and their replacement by younger, better qualified workers. In both countries, we find that labor quality growth was positive throughout the 1990s, though in both the rate of growth decelerated. ${ }^{12}$

\subsection{RESULT FROM TRADITIONAL GROWTH ACCOUNTING}

Tables 4 and 5 provide standard estimates of TFP for various aggregates, including the 1-digit industry level. The first three columns show TFP in gross-output terms. Since aggregate TFP is a value-added concept, we present industry TFP in value-added terms as well; by controlling for differences in intermediate input intensity, these figures are 'scaled' to be comparable to the aggregate figures. The final column shows the sector's nominal value-added share. ${ }^{13}$

We start by discussing the U.S. results in Table 4, focusing on the value-added measures. The top line shows the sizeable acceleration in TFP growth, from about 0.6 percent per year to about 1.9 percent. $^{14}$ These calculations incorporate labor quality adjustments from Aaronson and Sullivan (2001), shown in the second line. Labor quality growth grew more slowly in the second half of the 1990s, when the booming economy drew lower

\footnotetext{
${ }^{10}$ Gust and Marquez (2000) and van Ark et al. (2002) also find that differences in national accounts methodology cannot explain the productivity growth gap between the U.S. and Europe.

${ }^{11}$ Quality-adjusted hours is a Törnqvist index of hours worked by 40 groups, where each group's hours are weighted by its share of the aggregate wage bill. The groups consist of 4 qualifications groups (degree, A level, O level and "other") and 5 age groups (covering ages 16-65), for each sex.

12 See Tables 4 and 5 below, line 2 labeled "labor quality adjustment".

${ }^{13}$ With Törnqvist aggregation, aggregate TFP growth is a weighted average of industry gross-output TFP growth, where the so-called 'Domar weights' equal nominal industry gross output divided by aggregate value added; the weights thus sum to more than one. In continuous time, this is equivalent to first converting gross-output residuals to value-added terms by dividing by (one minus the intermediate share), and then using shares in nominal value added. (In discrete time, using average shares from adjacent periods, they are approximately equivalent.) Basu and Fernald (2001) discuss this aggregation and its extension to the case of imperfect competition; see also Oulton (2001a).

${ }^{14}$ As noted earlier, the acceleration exceeds that in product-side BLS data shown in Table 1.
} 
skilled workers into employment. Hence, adjusting for labor quality growth heightens the magnitude of the TFP acceleration calculated with raw hours (shown in the third line, calculated as the appropriate weighted average of the industry TFP growth rates shown in the table).

The remainder of the table shows various sub-aggregates, including the 1-digit SIC level (none of which incorporate a labor quality adjustment). It is clear that in our dataset, the acceleration was not limited to the ICT-producing sectors. First, if we focus on the non-ICT producing sectors (third line from bottom), they show an acceleration of nearly a percentage point. In an accounting sense, these sectors contribute about 0.9 percentage points of the 1.2 percentage point total (non-quality adjusted) acceleration. Major non-ICT sectors contributing to the acceleration include wholesale trade; retail trade; finance; and insurance.

Second, Griliches (1994) and Nordhaus (2002) argue that real output in many service industries are poorly measured-e.g., it is often difficult even conceptually to decide on the 'real output' of a bank or a lawyer; as another example, in health care, the hedonic issues are notoriously difficult. Nordhaus argues for focusing on what one hopes are the 'well-measured' (or at least, 'better measured') sectors of the economy. The acceleration in TFP in well-measured industries is even larger than the overall acceleration; the acceleration is sizeable even when we exclude ICT-producing sectors.

Table 5 shows the comparable table for the U.K. economy. Between the first and second halves of the 1990s, productivity growth fell in the U.K. private non-farm economy by about a percentage point, even after adjusting for the much slower growth in labor quality in the second half of the 1990s. Looking at major industries, TFP growth (unadjusted for labor quality) rose substantially in finance/insurance and manufacturing durables, but was flat or declined in most other major sectors.

By contrast, aggregate productivity growth rose in the U.S. by 1.3 percentage points per annum (Table 4), so the difference in acceleration was about 2.3 percentage points. Given this broad difference, there are some similarities in the sectoral pattern across the two countries. For example, the productivity acceleration was much faster in durables than in non-durables; finance and insurance surged.

Looking more closely at the sectoral data, a major difference between the U.S. and the U.K. is the trade sectors, especially retail. U.S. retail value-added TFP growth rose by 4.5 percentage points per year; U.K. TFP 
growth fell by about 1.7 percentage points. Nevertheless, they are not the entire story. Even excluding them, the U.S. data still show an acceleration, whereas the U.K. data still show a deceleration. ${ }^{15}$

That the U.S. productivity acceleration was broadbased is consistent with a growing body of recent work. For example, the Council of Economic Advisers (2003) reports that between 1973-1995 to 1995-2002, non-ICT TFP accelerated sharply, with its contribution to U.S. growth rising from 0.18 percentage points per year to 1.25 percentage points, roughly in line with the figures here. ${ }^{16}$ Bosworth and Triplett (2002) focus on the performance of service industries, and find a widespread acceleration. Jorgenson, Ho, and Stiroh (2002b) also find that TFP accelerated outside ICT production, although by a smaller amount.

\subsection{AUGMENTED GROWTH-ACCOUNTING CONSIDERATIONS}

Some research has looked at whether the results cited here are robust to deviations from the standard assumptions of growth accounting, generally concluding that they are. Using different methodologies, Basu, Fernald, and Shapiro (2001), Council of Economic Advisers (various years), and Baily and Lawrence (2001) find that cyclical mismeasurement of inputs plays little if any role in the U.S. acceleration of the late 1990s. Basu, Fernald, and Shapiro also find little role in the productivity acceleration for deviations from constant returns and perfect competition.

Basu, Fernald, and Shapiro do find a noticeable role for traditional adjustment costs associated with investment. Because investment rose sharply in the late 1990s, firms were, presumably, diverting an increasing amount of worker time to installing the new capital rather than producing marketable output. In other words, if there are costs of adjusting the capital stock and faster growth leads to higher costs, then true technological progress was faster than measured. These considerations strengthen the conclusion that the technology acceleration was broadbased, since service and trade industries invested heavily in the late 1990s and, hence, paid a lot of investment adjustment costs.

${ }^{15}$ Wholesale and retail trade "account" for about three-quarters of the U.S. acceleration (Domar weighted industry TFP growth), and one-third of the U.K. deceleration. McKinsey (2001) provides anecdotal as well as quantitative evidence on the transformation of wholesale and retail trade; Foster, Haltiwanger, and Krizan (2002) link the retail industry data to firm-level developments. We would note that Jorgenson, Ho, and Stiroh (2002), who use output data from the BLS Office of Employment Projections, do not find as important a contribution from the trade sectors.

${ }^{16}$ The CEA methodology is very similar to that of Oliner and Sichel (2002), who report no TFP acceleration outside of ICT production. But Oliner and Sichel discount their finding on this score, since their method takes non-ICT TFP is a residual. Since the Oliner-Sichel end-point is a recession year, 2001, they point out that any cyclical effects on productivity are forced to show up in non-ICT TFP. In addition, the CEA measure of labor productivity is a geometric average of income- and product-side measures of output per hour. 
The United Kingdom had even more sharply rising investment than did the United States, so conceivably adjustment costs might be masking an underlying improvement in U.K. productivity growth. From 1990-1995, aggregate investment in the U.K. private non-farm economy fell at 0.45 percent per year, while over 1995-2000 it rose at 8.60 percent per year. ${ }^{17}$ So how much of the decline in U.K. productivity growth might be attributable to adjustment costs? Following Basu, Fernald and Shapiro (2001), we calibrate these costs as a parameter $\phi$ times the growth rate of investment; following Shapiro (1986), they take $\phi$ to be $0.035{ }^{18}$ This calibration implies that investment adjustment costs held down measured TFP growth by about 0.30 percentage points per year over 1995-2000, but boosted it by 0.02 percentage points from 1990-95. Hence, the slowdown in true productivity growth was about 0.63 , not 0.95 , percentage points per annum. Hence, adjustment costs might account for about a third of the observed productivity deceleration.

Of course, the same correction would raises the U.S. technology acceleration by a bit under 0.2 percentage point. ${ }^{19}$ Hence, although this correction makes a larger difference to the U.K. data, it doesn't reverse the U.K. decline or even noticeably narrow the gap with the United States.

\section{Industry-Level Productivity Implications of ICT as a New GPT}

The U.S. productivity acceleration coincided with accelerated price declines for computers and semiconductors but, as we just saw, most of the TFP acceleration appears to have taken place outside of ICT production. Can ICT somehow explain the measured TFP acceleration in industries using ICT? We first discuss broad theoretical considerations of treating ICT as a new General-Purpose Technology (GPT), and then present a simple model to clarify the issues and empirical implications.

\subsection{GENERAL PURPOSE TECHNOLOGIES: "SPOOKY ACTION AT A DISTANCE”}

Standard neoclassical growth accountants identify several effects of ICT on aggregate labor and total factor productivity growth. Faster TFP growth in producing ICT contributes directly to aggregate TFP. In

\footnotetext{
${ }^{17}$ This estimate uses the same data employed to estimate capital services in the U.K. at the industry level.

${ }^{18}$ Shapiro does not estimate different values of $\phi$ for IT and non-IT capital; one could imagine that the values differ. We hope to estimate these values in future work.

${ }^{19}$ These numbers are qualitatively the same but smaller than those reported in Basu, Fernald, and Shapiro (2001) for three reasons. First, we have added an extra year of data (2000) in which investment growth was weak. Second, data revisions have reduced the growth rate of investment in the second half of the 1990s. Third, Jason Cummins and John
} 
addition, the use of ICT contributes directly to labor productivity through capital deepening: By reducing the user cost of capital, falling ICT prices induce firms to increase their desired capital stock. ${ }^{20}$

Standard growth accounting does not presume that the use of ICT has any particular effect on TFP. By contrast, many microeconomic, firm-level, and anecdotal studies suggest that there are important—but often indirect and hard to foresee-potential roles for ICT to affect measured production and productivity in sectors using ICT. Conceptually, one can separate these potential links into two categories: Purposeful co-invention, which we interpret as the accumulation of "complementary capital," which leads to mismeasurement of true technology; and externalities of one sort or another.

These indirect effects that arise from general purpose technologies such as ICT are akin to what Einstein, in the context of particle physics, called "spooky action at a distance": quantum physics predicts that in some circumstances, actions performed on a particle in one location instantaneously influence another particle that is arbitrarily far away. In terms of the effects of ICT, an innovation in one sector, ICT, often causes unexpected ripples of co-invention and co-investment in sectors that seem almost arbitrarily far away. Many of the GPT stories (e.g., Bresnahan and Trajtenberg, 1995, or Helpman and Trajtenberg, 1998) fall in the "spooky action" camp. (Of course, Einstein's spooky action was instantaneous; the effects of GPTs are not.)

First, firm-level studies suggest that benefiting from ICT investments requires substantial and costly co-investments in complementary capital. ${ }^{21}$ For example, firms that use computers more intensively may reorganize production, thereby creating 'intangible capital' in the form of organizational knowledge. These investments may include resources diverted to learning; they may involve purposeful innovation arising from R\&D. As Bresnahan (undated) argues, "advances in ICT shift the innovation possibility frontier of the economy rather than directly shifting the production frontier." I.e., ICT induces co-innovation and co-investment by firms using the technology, with long and variable lags.

The resulting "organizational capital" is analogous to physical capital in that companies accumulate it in a purposeful way. Conceptually, we can think of this complementary capital as an additional input into a

Roberts pointed out a mistake in our conversion from Shapiro (1986)'s framework to ours. This led us to reduce our estimate of $\phi$ from 0.048 in Basu, Fernald, and Shapiro (2001) to 0.035 in this work.

${ }^{20}$ Tevlin and Whelan (2000) for the U.S. and Bakhshi et al (2003) for the U.K. provide econometric evidence that falling relative prices of ICT equipment fuelled the ICT investment boom.

${ }^{21}$ See, for example, Brynjolfsson and Hitt (2000) and Bresnahan (undated) for a discussion of the kinds of complementary investments and co-invention that firms undertake in order to benefit from ICT, given its 'general purpose' attributes. David and Wright (1999) provide a nice historical reflection on general purpose technologies. 
standard neoclassical production function; it differs from ordinary capital and labor in that it is not directly observed but must, somehow, be inferred. ${ }^{22}$

Second, the GPT literature suggests the likelihood of sizeable externalities to ICT. For example, successful new managerial ideas-including those that take advantage of ICT, such as the use of a new business information system—seem likely to diffuse to other firms. Imitation is often easier and less costly than the initial co-invention of, say, a new organization change, because you learn by watching and analyzing the experimentation, the successes and, importantly, the mistakes made by others. ${ }^{23}$ Indeed, firms that don't use computers more intensively may also benefit from spillovers of intangible capital. For example, if there are sizeable spillovers to $R \& D$, and if $R \& D$ is more productive with better computers, then even firms that don't use computers intensively may benefit from the knowledge created by computers.

These GPT considerations are completely consistent with the traditional growth accounting framework but suggest difficulties in implementation and interpretation. In particular, these considerations suggest that the production function is mismeasured because we don't observe all inputs (the service flow from complementary, intangible capital) or all outputs (the investment in complementary capital). Hence, TFP is mismeasured.

Note that the 'spooky action' nature of the co-inventions and externalities suggests that we should not expect the benefits of ICT to diffuse quickly across borders. First, if large complementary investments and innovations are necessary, diffusion will inevitably take time. Second, Bresnahan and Trajtenberg (1995) note that co-invention often requires "coordination between agents located far from each other along the time and technology dimension" (p.3), so that institutional arrangements and market structure-which affect the ability to contract successfully in an environment with asymmetric information and uncertain property rights—are likely to matter; these factors are likely to differ across countries. Third, adoption costs may differ across countries, just as they seem to differ across firms, so that low adjustment/adoption cost countries may adopt new technologies first. These differences in cost may reflect the presence or absence of complementary factors-

\footnotetext{
${ }^{22}$ Much of Brynjolfsson's work tries to quantify the role of unobserved complementary capital. Macroeconomic studies of the effects of organizational capital include Greenwood and Yorokoglu (1997), Hornstein and Krusell (1996), Hall (2001), and Laitner and Stolyarov (2001).

${ }^{23}$ Bresnahan (undated) provides a nice discussion of the channels for externalities to operate. Bresnahan and Trajtenberg (1995) highlight both 'vertical' externalities (between general purpose technology producers and each application sector) and 'horizontal' externalities (across application sectors).
} 
business-school-trained managers, for example—or the vintage structure of the existing capital stock. ${ }^{24}$ Finally`, spillover effects may be stronger at closer distances (e.g., within Silicon Valley).

In looking at the U.S. versus the U.K., this discussion makes clear the difficulty of the task at hand: we need to find a way to infer unobserved complementary investments. That is, the U.S. could be benefiting from past intangible investments in knowledge and reorganization, leading to high measured TFP growth; the U.K. might have begun heavy intangible complementary investment only more recently, diverting resources from production of market output and appearing to have low TFP growth. We now turn to a formal model that suggests variables that might proxy for these unobservables.

\subsection{INDUSTRY-LEVEL IMPLICATIONS OF ICT AS A NEW GPT: A SIMPLE MODEL}

The last 10 years, and especially the last five, have seen an explosion in papers modeling the effects of "general-purpose technologies" (GPTs), and interpreting the ICT revolution as the advent of such a technology. ${ }^{25}$ But it is quite difficult to derive industry-level empirical implications from this literature. For example, it is often unclear how to measure in practice some of the key variables, such as unobserved investment and capital; and even for observed variables, measurement conventions often depart from those used in national accounting. ${ }^{26}$

On the other hand, conventional industry-level growth-accounting studies of the sort reviewed and extended in Section 3 are typically hard to interpret in terms of GPT considerations because they generally lack a conceptual, general equilibrium framework to interpret movements in TFP. Although some studies try to look for a "new economy" in which ICT has indirect effects on measured TFP in ICT-using industries, in the absence of clear theoretical guidance, it is not clear that many would know if they had, in fact, found it.

Finally, as discussed above, a large empirical literature, often using firm-level data or case studies, stresses the importance and costly nature of organizational change accompanying ITC investment. This literature, while

\footnotetext{
${ }^{24}$ Chandler (1977), for example, highlights the rise of professional managerial skills. In addition, new technologies may be somewhat specific to a country's particular cultural and institutional arrangements-society's general 'organization', 'infrastructure', 'social capital', and the like. In other words, 'appropriate technology' may matter even in comparisons of the U.S. versus U.K. companies. This is related to the literature on factors that affect costs of adopting a new GPT. Helpman and Trajtenberg (1998), for example, have some interesting examples of which industries adopted semiconductors first—e.g., hearing aids and computers, where the existing technology was inadequate; and which adapted late, notably telecom and automotives, with a large body of vintage capital.

${ }^{25}$ A very incomplete list is Caselli (1999), Greenwood and Yorukoglu (1997), the collection of papers edited by Helpman (1998), Hobijn and Jovanovic (2001), Jovanovic and Rousseau (2003), and Laitner and Stolyarov (2001).
} 
important and insightful, rarely makes contact with economy-wide productivity research. ${ }^{27}$ In many ways, our empirical work below is a tentative attempt to make just that connection. The model below provides the bare bones of a theoretical framework to capture some of the key issues, focusing on cross-industry empirical implications. Our model takes as given the arrival of a particular GPT, which here is taken to be the production of ICT capital at a continuously falling relative price. The distinguishing feature of a GPT is that its effects are general—going well beyond the industry of production—but require complementary investments by firms in order to fully benefit from its use. For empirical implementation, we focus on industries that use the GPT.

Value added in industries that use, but do not produce, IT is given $b^{28}$ :

$$
Q_{i t} \equiv Y_{i t}+A_{i t}=F\left(Z_{t} G\left(K_{i t}^{I T}, C_{i t}\right), K_{i t}^{N T}, L_{i t}\right), \quad i=1, \ldots N
$$

where $F$ and $G$ are homogeneous of degree 1 in their arguments. $Z$ is a technology term that each industry takes as exogenous. We discuss the distinction between $A$ and $Y$ shortly. For simplicity, we are ignoring materials input (although we add it back in our empirical work), imperfect competition, increasing returns, and capital adjustment costs. All could be added, at the cost of considerable notation.

Each industry rents ICT capital $K^{I T}$ and non-ICT capital $K^{N T}$ in competitive, economy-wide markets. The aggregate stocks of the two types of capital evolve as:

$$
K_{t}^{J T}=I_{t}^{J T}+\left(1-\delta^{J T}\right) K_{t-1}^{J T}, \quad J=I, N
$$

Industries must, however, individually accumulate their stocks of complementary capital, $C$. We think of this capital as business and organizational models or training in the use of IT, and the investment flow $A$ as the time and resource cost of training and creating new business structures. ${ }^{29}$ Industries forego producing market output $Y$ to accumulate this capital:

$$
C_{i t}=A_{i t}+\left(1-\delta_{C}\right) C_{i t-1}
$$

${ }^{26}$ For example, capital is typically measured as foregone consumption, which is sensible for an aggregative model but difficult to relate to industry-level capital accounts that deal with capital heterogeneity and quality change by (attempting to) measure capital input in efficiency units. Howitt (1998) attempts to bridge the two conventions

27 An exception is Brynjolfsson and Yang (2001).

${ }^{28}$ With constant returns and competition, one can speak of firms and industries interchangeably. "An industry does $\mathrm{x}$ " is our shorthand for "all firms in an industry do x."

${ }^{29}$ Chandler (1977) discusses innovations in inventory management made possible by railroads. Wal-Mart inventory management system provides an example of innovations made possible by ITC. 
We assume that investment in all three kinds of capital is irreversible. Since both $A$ and $N T$ investment goods cost the same to produce, the economic difference between the two types of capital is that they interact in different ways with the ICT capital stock. The difference from the point of view of measurement is that $Y$ is measured in the national income accounts, but $A$ is not. ${ }^{30}$

The main economic implication of the separability assumption built into (4.1) is that the marginal productivities of $K^{I T}$ and $C$ are closely tied to one another. We assume that the elasticity of substitution between the two inputs in the production of $G$ is relatively small. We also assume Inada-like conditions to the effect that the marginal productivity of each input is very low if the level of the other is close to zero. Thus, when the GPT arrives and ICT capital starts getting cheap, the incentive to also accumulate $C$ is very strong.

Note that conceptually, 'innovation' as traditionally construed can take two forms. First, we lump purposeful innovations into $C$ (indeed, we have assumed that all purposeful innovation is closely linked to ICT). Second, we interpret $Z$ as all 'exogenous' increases in technology, including, for example, the component of organizational change that spills over from the sector of origin —-for example, the idea of using individual electric motors at each workstation in a factory, rather than relying on the single drive train of a steam engine.

\subsection{TFP MEASUREMENT WITH UNOBSERVED INPUTS AND OUTPUT}

What are the implications of complementary capital accumulation for the measured TFP of ICT-using industries? Differentiating, we can write the production function in growth rates as:

$$
\Delta q=\frac{F_{K^{I T}} K^{I T}}{Q} \Delta k^{I T}+\frac{F_{C} C}{Q} \Delta c+\frac{F_{K^{N T}} K^{N T}}{Q} \Delta k^{N T}+\frac{F_{L} L}{Q} \Delta l+s_{G} \Delta z
$$

Since we have made Solow's assumptions of constant returns to scale and perfect competition, we have

$$
\frac{F_{K^{I T}} K^{I T}}{Q}+\frac{F_{C} C}{Q}+\frac{F_{K^{N T}} K^{N T}}{Q}+\frac{F_{L} L}{Q}=1
$$

If we observed total output $Q$, and knew the required rates of return to capital, we could back out the elasticity of output with respect to complementary capital, $C$ :

$$
\frac{F_{C} C}{Q}=1-\frac{W L}{P Q}-\frac{P_{K}^{I T} K^{I T}}{P Q}-\frac{P_{K}^{N T} K^{N T}}{P Q} .
$$

30 Some fraction of $A$ is probably measured: for example, consultant services and many forms of software. It is not clear how much of what is measured is properly capitalized, as required by equation (4.3). 
Without independent information on the flow of $A$ or the stock of $C$ (perhaps from stock market valuations), one cannot implement this procedure using measured output, $Y^{N T}$. Rewrite equation (4.6) as:

$$
\frac{F_{C} C}{Y^{N T}}=\frac{Q}{Y^{N T}}-\frac{W L}{P Y^{N T}}-\frac{P_{K}^{I T} K^{I T}}{P Y^{N T}}-\frac{P_{K}^{N T} K^{N T}}{P Y^{N T}}
$$

Since $Q / Y^{N T}$ is not observed, within broad limits we are free to believe that complementary capital is arbitrarily important in production by assuming that an arbitrarily large share of the true output that firms produce is not counted in the National Accounts.

Some algebraic manipulations of (4.4) yield an expression for the conventional Solow residual:

$$
\begin{aligned}
& \Delta y^{N T}-\frac{P_{K^{I T}} K^{I T}}{P Y^{N T}} \Delta k^{I T}-\frac{P_{K^{N T}} K^{N T}}{P Y^{N T}} \Delta k^{N T}-\frac{F_{L} L}{Q} \Delta l \\
& \equiv \Delta T F P=\frac{F_{C} C}{Y^{N T}} \Delta c-\frac{A}{Y^{N T}} \Delta a+s_{G} \Delta z
\end{aligned}
$$

We see that omitting complementary inputs can cause us to either overestimate or underestimate TFP growth. When unmeasured output is growing $(\Delta a>0)$, TFP growth is underestimated (the "1974" story) as resources are diverted to investment. When unmeasured input is growing $(\Delta c>0)$, TFP growth is overestimated. In steady state, of course, the accumulation equation implies that $\Delta c=\Delta a$ which, in turn, implies that the steady-state mismeasurement is

$$
\frac{C}{Y^{N T}}\left[F_{C}-\frac{A}{C}\right] g=\frac{C}{Y^{N T}}\left[\left(r^{*}+\delta_{C}\right)-\frac{g+\delta_{C}}{1+g}\right] g,
$$

where $r^{*}$ is the steady-state real interest rate. In a dynamically efficient economy, the mismeasurement is necessarily positive: True steady-state TFP growth is lower than measured, not higher.

This point is a simple one, but it is a quantitatively important correction to statements in the existing literature (e.g., Bessen, 2003). ${ }^{31}$ Of course, if one corrects only output mismeasurement $(\Delta a)$, then ICT will appear fantastically productive, far beyond what is ordinarily measured. But firms choose to divert resources to unobserved investment $\Delta a$ in order to create an intangible capital stock that contributes to future production. The resulting unmeasured flow of capital services implies a bias in the other direction. The net bias may be either positive or negative at a point in time, but is positive in the steady state.

\footnotetext{
${ }^{31}$ Laitner and Stolyarov (2001) also stress the importance of including complementary capital in a growth accounting exercise.
} 
We now seek an observable proxy for unobserved investment in, and growth in the stock of, complementary capital. In light of the firm-level evidence, observed growth in ICT capital provides a reasonable proxy. Suppose $G$ takes a CES form:

$$
G=\left[\alpha K^{I T} \frac{\sigma-1}{\sigma}+(1-\alpha) C^{\frac{\sigma-1}{\sigma}}\right]^{\frac{\sigma}{\sigma-1}}
$$

We consider the optimization sub-problem of producing $G$ at minimum cost, which firms solve every period. The solution of the sub-problem is:

$$
\Delta c_{t}=\Delta k_{t}^{I T}+\sigma \Delta p_{t}^{I T}
$$

where $\Delta p_{t}^{I T}$ is the change in the relative rental rate of ICT capital to C-capital. This equation implies a direct link between growth in complementary capital and growth of observed ICT capital.

We can use the accumulation equation to express unobserved investment $\Delta a$ in terms of current and lagged growth in unobserved capital $\Delta c$ :

$$
\Delta a_{t}=\frac{C}{A}\left[\Delta c_{t}-\frac{\left(1-\delta_{C}\right)}{(1+g)} \Delta c_{t-1}\right]
$$

Substituting the last equation and equation (4.8) into (4.7), we have in principle an equation for TFP growth that indicates the importance of complementary capital accumulation:

$$
\Delta T F P=\left[\frac{F_{C} C}{Y^{N T}}-\frac{C}{Y^{N T}}\right]\left[\Delta k_{t}^{I T}+\sigma \Delta p_{t}^{I T}\right]+\left[\frac{C}{Y^{N T}} \frac{\left(1-\delta_{C}\right)}{(1+g)}\right]\left[\Delta k_{t-1}^{I T}+\sigma \Delta p_{t-1}^{I T}\right]+s_{G} \Delta z
$$

The first term is proportional to $\left(r^{*}+\delta-1\right)$, so under reasonable circumstances it is negative. The second term, on the other hand, is clearly positive. Hence, our GPT-type framework implies that firms/industries that invest substantially in GPTs have lower current measured output, but higher future measured output. I.e., other things equal, industries that are making large IT investments today will have low measured TFP growth, but those that made such investments in the past will have high measured TFP growth. (This discussion is independent of any externalities, which may also be important.)

As an estimating equation, (4.9) has the difficulty that industries are likely to differ in their long-run $C / Y^{N T}$ ratios. Using the CES assumption for $G$, the cost-minimizing F.O.C. implies that

$$
\frac{K^{I T}}{C}=\left[\left(\frac{1-\alpha}{\alpha}\right)^{\sigma}\right]\left(\frac{P_{K}}{P}\right)^{-\sigma}
$$


or

$$
\frac{C}{Y^{N T}}=\frac{P C}{P_{K} K^{I T}} \frac{P_{K} K^{I T}}{P Y^{N T}}=\left[\left(\frac{1-\alpha}{\alpha}\right)^{\sigma}\right]\left(\frac{P_{K}}{P}\right)^{1-\sigma} s_{K^{I T}}
$$

In the convenient Cobb-Douglas case, we have that the $C / Y^{N T}$ ratio is proportional to the observed ICT share, so ceteris paribus the mismeasurement of complementary capital is more important in those industries where ICT capital is used to a greater extent- - a reasonable conclusion.

$$
\Delta T F P=\left[F_{C}-1\right] \beta \tilde{k}_{t}+\left[\frac{\left(1-\delta_{C}\right)}{(1+g)}\right] \beta \tilde{k}_{t-1}+s_{G} \Delta z,
$$

where $\tilde{k}_{t}=\left(\frac{P_{K}}{P}\right)^{1-\sigma} s_{K^{I C T}}\left[\Delta k_{t}^{I C T}+\sigma \Delta p_{t}^{I C T}\right]$ and $\beta=\left(\frac{1-\alpha}{\alpha}\right)^{\sigma}$.

As an alternative way of implementing equation (4.7), when can we take ICT investment as a direct proxy for unobserved complementary capital investment? Combining the accumulation equations for complementary capital and ICT capital implies:

$$
\frac{A_{i t}}{C_{i t}}=\frac{I_{i t}}{K_{i t-1}}+\left(\delta_{C}-\delta_{I C T}\right)+\sigma \Delta p^{I C T}
$$

If $\delta_{C}=\delta_{I C T}$ and $\sigma=0$, then $\Delta a=\Delta i^{I C T}$. This implies that:

$$
\begin{gathered}
\Delta T F P_{i t}=F_{C} \tilde{k}_{i t}-\left(\frac{P A}{P_{I} I}\right)\left(\frac{P_{I} I}{P Y}\right) \Delta i_{i t}^{I C T}+s_{G} \Delta z_{i t} \\
=F_{C} \tilde{k}_{i t}-b \tilde{i}_{i t}+s_{G} d z_{i t} \text {, where } \tilde{i}_{i t}=s_{i t}^{I} \Delta i_{i t}^{I C T} .
\end{gathered}
$$

Note that the capital and investment terms incorporate the income share of complementary capital and the share of complementary investment in output, which are likely to differ greatly across industries. So we are assuming that the complementary shares are correlated across industries with the ICT shares.

When will equation (4.10) be preferable to equation (4.11)? The key issue is the lag between ICT investment and complementary investment. For example, suppose a company invested heavily in an expensive enterprise resource management system in the mid-1980s and then spent the next decade learning how best to reorganize to benefit from the improved information availability. Then equation (4.10)—with very long lagsshould work well. By contrast, if the reorganization was contemporaneous with the ICT investment, then 
equation (4.11) should work well (assuming the other conditions involved in deriving it are not too unreasonable) and there might not be long lags.

Our method of using cost-minimization conditions to proxy for unobserved variables from observables is common in the literature on cyclical productivity with unobserved factor input (utilization). ${ }^{32}$ As in that literature, it can imply a fairly elaborate proxy, which may not be easy to estimate. Given that fact, should we try to follow Hall (2001) and several other authors, who measure the importance of organizational capital from the gap between firms' stock market valuations and the replacement values of their physical capital ? $^{33}$

We do not do so, for two reasons. First, given the importance of the issue, it is interesting to investigate a different approach to estimation and see if we get broadly the same answer. Second, given the recent large swings in equity markets, we are wary of any attempt to impute the real service flow of the stock of organizational capital from stock-market valuations. Setting aside the usual concerns about stock market bubbles, suppose the recent fall in equity prices is due to the realization that much of the current "e-capital" will become obsolete sooner than previously expected. This information will appropriately lead to a lower market value of the capital, but does not imply that its current real service flow into production must be lower. ${ }^{34}$

\subsection{EXTENSIONS TO THE BASIC FRAMEWORK}

Clearly, the implications of a new GPT for measured productivity growth are subtle and may be hard to distinguish from alternatives. But the theory does suggest that one needs lags of ICT capital growth in the TFP equation, in addition to the current growth rate. ${ }^{35}$

One complication is that the externality captured in $\Delta z$ can be a function of industry $C_{i}$, as well as aggregate $C$. In that plausible case, one can no longer tell whether the capital growth terms in equation (4.9) represent accumulation of a private stock, or intra-industry externalities that are internalized within the industry. Similarly, if we find that lagged $\Delta k^{I T}$ is important for explaining current productivity growth we do not know

${ }^{32}$ See, for example, Basu and Kimball (1997).

${ }^{33}$ See Brynjolfsson and Yang (2001) for an example of this alternative approach.

${ }^{34}$ Formally, capital aggregation theory shows that the service flow of capital is proportional to the value of the stock only if depreciation occurs at a constant, exponential rate. A large, one-time capital loss is an excellent example of a non-constant depreciation rate. Jovanovic and Rousseau (2003) make exactly the same argument about changes in stock market valuation when a GPT is introduced. But given the false starts and dead ends that often accompany a recentlyintroduced GPT, their logic should apply equally to episodes after the GPT is introduced but before it has become a mature technology. (Think, for example, of DC power generation in the United States.) 
whether that finding supports the theory we have outlined, or whether it indicates that the externality is a function of lagged capital.

In addition, a free parameter is the length of a period, a point on which the theory gives us no guidance. The lagged $\Delta k^{I T}$ may be last year's ITC capital accumulation, or the last decade's. Furthermore, equation (4.3) for the accumulation of complementary capital has no adjustment costs, or time-to-build or time-to-plan lags in the accumulation of $C$. But such frictions and lags are likely to be important in practice, making it even harder to uncover the link between ICT and measured TFP.

One further concern is whether other variables should enter the production function for $A$, which we do not account for here. Our framework implicitly assumes the same production function for $A$ and $Y$. But it is possible, as many have recognized, that the production of complementary capital is particularly intensive in skilled (i.e., college-educated) labor. ${ }^{36}$ This hypothesis is particularly interesting given the noticeable difference between the U.S. and the U.K. in the fraction of skilled workers that we documented in Table 3. If true, the hypothesis implies that the relative price of accumulating complementary capital may differ significantly across the two countries (and perhaps across industries within a country) in ways that we may not be able to capture.

\section{Evidence for the GPT hypothesis}

\section{1 $\quad$ EMPIRICAL EVIDENCE ON THE ROLE OF ICT}

We concluded earlier that much of the U.S. acceleration in measured TFP reflects an acceleration outside of the production of ICT products. TFP can move around for a lot of reasons unrelated to ICT. For example, it could be that the United States experienced broad-based managerial innovations that raised TFP growth throughout the economy. Nevertheless, the previous section suggests that the acceleration-and managerial innovations - could be associated with the use of ICT.

Several studies explore whether TFP growth across industries is correlated with ICT intensity. In contrast to firm-level studies, these industry studies rarely find much correlation between ICT capital and TFP

35 Hence one needs to generalize the approach followed by, e.g., Stiroh (2002b), who argues against a spillovers/GPT story by regressing TFP growth on only the current-year growth rate of IT capital. Brynjolfsson and Hitt (2002) also find significant lags in firm-level data, which nicely complements our more aggregative evidence.

${ }^{36}$ In a different framework, Krueger and Kumar (2003) ask whether the different educational systems in the U.S. and Europe (especially Germany) may be responsible for their different growth experiences in the 1990s. See also Lynch and Nickell (2002). 
growth (e.g., Stiroh, 2002b and Wolff, 2002). But given the GPT nature of ICT, the contemporaneous correlation need not be positive- - even if ICT is, in fact, an important contributor to measured TFP.

Wolff does find that U.S. industries investing heavily in ICT have greater changes in their occupational mix and the composition of intermediate inputs, consistent with substantial reorganization. Gust and Marquez (2002) find that, in a sample of industrial countries, those with a more burdensome regulatory environmentparticularly regulations affecting labor market practices—adopted ICT more slowly and also had slower TFP growth. Those findings are consistent with the notion that the uptake of ICT could affect measured TFP in the sectors using the ICT. ${ }^{37}$

As discussed in Section 2, the Gust-Marquez regulatory variables look similar in the U.S. and U.K.. But an open question is whether, for other reasons, U.S. society was better able to undertake the disruptions associated with reorganization than was the United Kingdom (or other countries).

\subsection{THE CROSS-INDUSTRY PATTERN OF ICT USE IN THE U.S. AND U.K.}

A small number of U.S. and U.K. industries account for a large share of ICT use. For example, finance/insurance and business services/real estate own a disproportionate share of computers and software; communications uses a majority of communications equipment. Manufacturing, which accounts for about a fifth of GDP in both countries, has only 14 to 16 percent of computers and software in the two countries.

Tables 6 and 7 show one measure of the importance of ICT capital—-the ICT income share, i.e., the ratio of profits attributable to ICT capital to value added. Between 1990 and 2000, the income share of ICT in the U.K. increased by almost 50 percent, rising from 4.30 percent to 6.26 percent. The biggest rises occurred in Communication $(+10.1$ percent), Wholesaling $(+3.5$ percent $)$ and Non-durables $(+2.66$ percent $)$. The overall share is now above the corresponding figure for the U.S., 5.50 percent, which rose by much less in the 1990s. In short, on this measure the U.K. has caught up.

These income shares are central for growth accounting since the contribution of ICT capital to output growth uses these shares as weights on growth in ICT capital services. That these shares are now similar means

\footnotetext{
${ }^{37}$ In terms of standard growth-accounting, van Ark et al (2002) compare the U.S. and E.U., applying U.S. deflators for ICT and equipment. (Earlier comparisons by Daveri (2002) and Schreyer (2000), using private sector sources for ICT investment and stocks, and Colecchia and Schreyer (2002), using national accounts data, find results broadly consistent with those of van Ark et al.) They find that the E.U. and U.S. had similar ICT growth rates over 1980-2000. But the E.U. had a lower level of ICT investment. Consequently, the income share of ICT is much lower in the E.U. As a result, van Ark et al. (2002) find a smaller direct ICT contribution via capital deepening in the E.U.
} 
that we expect a given growth in ICT capital to have the same impact on output growth. In addition, the GPT model above suggests that unobserved complementary capital should be closely related to observed shareweighted ICT capital growth (perhaps with an adjustment for the relative price of ICT).

\subsection{CROSS-INDUSTRY EVIDENCE ON THE ROLE OF COMPLEMENTARY INVESTMENT}

We now present some preliminary cross-sectional industry evidence for the U.S. and U.K. that is, broadly speaking, consistent with the hypothesis that complementary investment associated with ICT has macroeconomic consequences. In particular, we explore the correlations between productivity growth (or the productivity acceleration) in the second half of the 1990s and various measures of ICT growth.

Such regressions are, of course, fraught with the potential for misspecification, given the uncertainty about how long it takes to build complementary capital and how long it takes for any spillovers to occur. In addition, given the difficulty of identifying valid instruments, all of our regression results are OLS; they capture any correlation between true non-ICT-related industry productivity growth and accumulation of ICT capital, regardless of direction of causation (if causal at all). It follows that all of our regressions need to be interpreted with a high degree of caution, and should be interpreted in the spirit of data exploration. Nevertheless, the results suggest that the GPT model does help illuminate the effects of ICT on productivity.

We begin by estimating equation (4.10). One important difficulty in implementing this equation is that we don't know the length of time over which it should operate. The time lags will depend on factors such as the time it takes to learn/innovate/reorganize, which depend in large part on the adjustment costs associated with that complementary capital investment. Brynjolfsson and Hitt (2002) find evidence of long lags in firm-level data; Howitt (1998) calibrates a model to U.S. data, and finds that the beneficial effects of a new GPT will not be detected in conventional national accounts data for more than 20 years.

To capture these notions in a loose way, we consider the following:

$$
\Delta p_{i}^{95-00}=c_{i}+a \tilde{k}_{i}^{95-00}+b \tilde{k}_{i}^{90-95}+c \tilde{k}_{i}^{80-90}+\varepsilon_{i}
$$

In this regression, $\tilde{k}^{95-00}$, for example, represents the average value of $\tilde{k}$ for computers and software over the period 1995 to $2000 .{ }^{38}$ Thus, we regress average industry TFP growth over the $1995-2000$ period on

\footnotetext{
${ }^{38}$ The regressions including communcations equipment as part of ICT gave results that were less significantarguably because of lack of sufficient adjustment for quality change in communications equipment.
} 
average share-weighted computer-and-software capital growth in the 1980s, early 1990s, and late 1990s. (We ignore the relative price terms in these regressions.)

We take this equation for each industry as a cross-sectional observation. This approach imposes an identical constant term on each industry, so that any industry-specific fixed effects show up in the error term. ${ }^{39}$ Thus, this regression will tell us, simply as a matter of data description, whether we can relate productivity growth to relatively current as well as lagged ICT investment in the cross section. Given that we are running an OLS regression, we cannot, of course, infer causation from the results. But this regression tells us whether productivity growth from 1995-2000 was larger in industries that had rapid share-weighted ICT growth in the late or early 1990s, the 1980s, or none of the above (with minimal restrictions on the timing and stability; these are likely to differ across industries). In the results that follow, we omit ICT-producing industries, in order to focus on links between ICT use and TFP. (Including ICT producers generally has little effect on coefficients.)

We report results for only the following measures of $\tilde{k}$ :

$$
\tilde{k}=\mathbf{s}_{\mathrm{K}_{\text {СOMP }}} \Delta \ln k_{\text {COMP }}
$$

Figure 1 plots this measure for the total economy-wide ICT and computer capital in the U.K. and U.S.

The figure shows substantial fluctuations over time for $\tilde{k}$ in the U.K. and a more stable pattern for the U.S., especially since 1990 . This measure of $\tilde{k}$ drops the relative price terms from the alternatives discussed; regression results below appeared more stable with this measure than the alternatives, although qualitative results were generally similar.

The first column of Table 8 shows that for the United States, the data are reasonably consistent with the predictions of the theory section that, with long lags, ICT capital growth should be positively associated with TFP growth; and that, controlling for past investments, contemporaneous ICT capital growth should be negatively associated with TFP growth. The data definitely want different coefficients across the well-measured and poorly measured groups, which we have addressed by interacting a 'poorly measured' dummy with all righthand-side variables. ${ }^{40}$

\footnotetext{
${ }^{39} \mathrm{We}$ find similar results for a specification that removes these fixed effects by making the dependent variable the change in TFP growth from 1990-95 to 1995-2000.

${ }^{40}$ The point estimates give a reasonable summary of what happens when we estimate regressions for the two groups separately.
} 
We find that for both groups, ICT capital investments in the 1980s are positively correlated with the TFP acceleration in the late 1990s. For the poorly measured industries, ICT capital investments from the early 1990s were also positively associated with the TFP acceleration. In the late 1990s, by contrast, share-weighted capital growth is negatively correlated with the TFP acceleration, statistically significantly so for the poorly measured industries. The results for the poorly measured industries are consistent with the firm-level evidence in Bryjolfsson and Hitt (2002), which also suggest a lag length of about five years for U.S. firms.

These results are fairly robust to outliers. Two influential observations (based on the Belsley-Kuh-Welsch 'hat matrix' test) ${ }^{41}$ are wholesale and retail trade. Given the importance of those two industries in the growth accounting, we experimented with omitting them. Doing so makes 1980s growth less important but 1990s growth more important-1990-95 is more positive, and 1995-2000 is more negative. These results could reflect that wholesale and retail trade have particularly long lags because of the importance of complementary capital. They may also be industries where 'endogeneity' is particularly important (for reasons unrelated to GPT arguments, ICT grew a lot in the late 1990s just when the scale of complementary investment was waning. $)^{42}$

For the U.K., the same regression shows little. ${ }^{43}$ Almost nothing is statistically significant; and the signs are reversed from what theory suggested. The lack of significance could reflect mismeasurement-the industry ICT capital stock data for the 1980s are not that reliable. But taken at face value, these results suggest that either the slowdown in U.K. TFP growth was not driven by complementary capital investment; that our ICT-based proxy for such investment works particularly poorly in the U.K. (perhaps because our specification is too simple); or because the timing assumptions embedded in the estimating equation (on lags between observed ICT investment and unobserved complementary investments) do not match the U.K. experience.

Table 9 shows results from our second specification, equation (4.11), which we term the investment accelerator specification. As noted in the theory discussion, this equation may perform better if the

\footnotetext{
${ }^{41}$ One standard statistical test is to look at the diagonal of the 'hat' matrix, $\mathrm{X}^{\prime}\left(\mathrm{X}^{\prime} \mathrm{X}\right)^{-1} \mathrm{X}^{\prime}$. For a regression with $k$ coefficients and $n$ observations, Belsley, Kuh, and Welsch (1980) identify influential observations as those where the diagonal element of the hat matrix exceeds $2 \mathrm{k} / \mathrm{n}$.

${ }^{42}$ Overall, results for the U.S. appear robust to outliers. Using the Belsley-Kuh-Welsch 'hat matrix' test, influential observations telephone and telegraph; wholesale and retail trade; depository and non-depository institutions; securities brokers; real estate; and business services. When those observations (who account for about 1/3 of GDP) are omitted, there is no evidence that poorly measured and well-measured industries look different-including the dummy variables would have only minor effects on coefficients or even standard errors. When these outliers are omitted, the data suggest that lagged growth of share-weighted computers and software are positively correlated with late-1990s TFP growth, whereas contemporaneous growth is negatively correlated with TFP.

${ }^{43}$ Due to concerns about the data, we drop rail transport, leaving 29 industries.
} 
complementary investment is closely correlated in time with the ICT investment. We can estimate this equation as it stands as a cross section, for different time periods. When we do so, we find the right hand side variables are insignificant. This is not surprising since in the specification the constant term differs across industries and may well be correlated with the explanatory variables. But a cross section regression imposes a common constant. Hence we prefer to take first differences of both sides, thus eliminating the fixed effects. Our dependent variable is now the acceleration of TFP growth: i.e., average TFP growth in 1995-2000 minus average TFP growth in 1990-1995. The ICT and investment deepening terms are defined analogously as changes in weighted growth rates. The estimating equation thus becomes:

$$
\left(\Delta T F P_{i, 1995-2000}-\Delta T F P_{i, 1990-1995}\right)=c_{i}+a\left(\tilde{k}_{i, 1995-2000}-\tilde{k}_{i, 1990-1995}\right)-b\left(\tilde{i}_{i, 1995-2000}-\tilde{i}_{i, 1990-1995}\right)+\varepsilon_{i}
$$

Table 9 shows these results. For the U.S., this equation shows little, basically reflecting the point made above, that the U.S. data want long lags.

By contrast, in the U.K., the coefficients have the expected signs and are statistically significant. As expected, ICT capital deepening enters with a positive sign, and is significant. Also as expected, investment deepening has a negative sign; we find that it too is significant. Three industries are influential according to the "hat" matrix, but dropping these has little effect on the results.

This result is highly suggestive. But there is an important qualification. Multiplying these means by their respective coefficients, we find that capital deepening would have raised TFP growth on average by 0.93 percent per annum, while investment deepening would have lowered it by 0.47 percent per annum, for a net positive effect of 0.46 percent per annum. So though investment deepening did serve to retard measured TFP growth, it cannot be said to account for the absolute fall in TFP growth.

On the other hand, one would expect endogeneity considerations to be particularly important in this equation, in a way that works against finding results consistent with the GPT hypothesis, even if true. In this specification, we regress the TFP acceleration on the contemporaneous investment acceleration. Because investment is endogenous, a positive industry-specific technology shock could lead to higher investment as well as higher TFP, thereby biasing the coefficient on investment upward. Hence, the true investment coefficient may be more negative than we find in our OLS regression.

In sum, the U.S. evidence is consistent with the notion that ICT investments affect measured productivity growth with a long (but variable) lag. Contemporaneously, they are correlated with a lot of 
diverted resources towards unmeasured complementary investment, and hence—once one controls for lagged growth rates-they are negatively correlated with output. It appears that in the U.K., the rapid growth of ICT investment after 1995 — which was higher than the growth of the ICT capital stock — appreciably retarded the measured growth of productivity. Comparing the second with the first half of the 1990s, the change in TFP growth is positively and significantly related to the change in ICT capital deepening. But it appears significantly and negatively associated with ICT investment growth. In the long run, of course, ICT capital and investment must grow at the same rate. So this suggests one reason for thinking that TFP growth in the U.K. must eventually recover, at least somewhat. The U.K. data suggest that the lags are much shorter-and that complementary investment was going on in the late 1990s. But although this effect is present, it is not large enough to explain the TFP slowdown in the U.K. in the late 1990s.

\subsection{EXPLAINING THE U.K. EXPERIENCE}

The basic story that we wish to tell based on our simple model of complementary capital investment is one where measured output growth is contemporaneously low when complementary investment is high, and high in periods after such investment has taken place and the stock of complementary capital is high.

Furthermore, the theory suggests that complementary capital investment will generally be high when observed investment in ICT capital times the share of such capital is high.

Apart from the evidence presented in Table 9, another reason we took this approach is that the aggregate data appear consistent with this story. Look at the summary statistics by sub-sample for the U.S. and the U.K. given in Table 1, and at Figure 1. The regressions used the industry-level versions of the variable plotted in the top panel of Figure 1, the computer share times the growth rate of the computer stock, but we also plot the analogous series for software in the lower panel. We conclude that the U.K. had far larger swings in this key variable than did the U.S., especially in the period before 1995. As we discussed before, the regressions with U.S. data support the hypothesis that the positive effects of IT investment and-we assume-complementary capital investment show up in measured output with a lag of about five years. (Two important industries in the U.S., wholesale and retail trade, prefer longer lags, but these industries are not as important for explaining the U.K. experience as they are for the U.S.)

If investments become productive with roughly a five-year lag, Figure 1 shows that the broad outlines of the macro experience in the U.K. are consistent with the story that we are telling. Note that the U.K. had 
extremely high levels of $\tilde{k}$ for both computers and software in the 1985-90 period, and both dropped sharply in the 1990-95 period as the U.K. fell into a deep recession. Our story suggests that measured TFP growth in 1985-90 should have been low, and measured growth in 1990-95 should have been high. This is the pattern one finds in Table 1, where TFP growth in 1985-90 was 1.2 percent, and growth in 1990-95 was 1.6 percent. Note that this difference is almost certainly understated, because the TFP numbers have not been corrected for cyclical mismeasurement coming from changes in utilization. The period of the late 1980s was a time of strong output and fixed investment growth (3.1 and 7 percent, respectively), while the figures for the early 1990s are 1.8 and -0.8 percent. It is amazing that a period with a deep recession should show an increase in measured TFP growth at all, and indicates to us that the effects of IT and complementary capital investment may be quantitatively important.

If one accepts this story, then it should be unsurprising that the next five years were bad ones for measured TFP growth in the U.K. The reason is two-fold. First, the level of IT investment in the previous five years was low, so the contribution of complementary capital was presumably low. Second, the U.K. also had a very steep increase in computer and software investment in the second half of the 1990s-in many ways a stronger surge than the one labeled historic in the U.S. According to our story, this should also have been a time of high unmeasured investment in complementary capital. Both considerations have the effect of reducing measured TFP growth.

There is also suggestive evidence consistent with the idea that the U.K. was experiencing a surge of supply-driven growth in the period 1995-2000. Note that over this period the U.K. was going from a deep slump to a boom. The average growth rate of output grew by 1 percentage point, and of investment by 7.2 percentage points, while unemployment fell a full 2.8 percentage points to 6.7 percent, a level not seen for decades. And in the midst of this boom, the inflation rate also fell, by 1.4 percentage points to 2.5 percent. Admittedly, it is not clear that embedding our story in a short-run macro model must lead to this result, since we claim that TFP growth was higher than recorded because output growth was also higher than recorded, which should have put extra upward pressure on prices. But it is suggestive, in part because it is difficult to see how else one might reconcile the full set of facts.

Having said all this, it remains true that although regression results for U.K. industries are somewhat consistent with this GPT story, the point estimates do not allow us to explain the recent growth and TFP 
experience based on investment in unmeasured complementary capital. That is, the regression suggests that the net effect of ICT is to raise, not lower, TFP growth when comparing the first and second halves of the 1990s.

But as we have already discussed, the form of the equation that appears to work better for the U.K. is also subject to larger endogeneity concerns, with a bias against finding support for the GPT view; this provides a potential, but so far only speculative, reconciliation. A second possibility is that the accumulation of complementary capital requires large inputs of skilled labor. This suggests that our proxy for complementary investment may be too simple; we may also need to allow for cross-industry variations in skill intensity. Indeed, it could be that even if complementary investment explains the divergent TFP performance, it is not, in fact, as closely linked to ICT capital accumulation in the U.K. as in the U.S.

\section{Conclusions}

The "crime" or puzzle we investigated in this paper was the slowdown in U.K. productivity growth, both TFP and labor, in the second half of the 1990s, which coincided with rising U.S. productivity growth. We found that for the private non-farm economy, the slowdown was nearly a percentage point. Moreover, the slowdown was particularly marked in industries like wholesale and retail trade that were among the major contributors to the U.S. improvement.

Many proposed explanations for the weak U.K. productivity performance seem insufficient. For example, the differences do not reflect differences in the importance of ICT production or a failure to account for falling labor quality. Nor do the genuine differences in national accounts methodology explain the differences: the U.K. slowdown persists even when the same methodology is applied to both countries.

Earlier work for the U.S. suggested that the disruption cost associated with investment might play a role since, in periods when investment is rising, such costs may reduce measured productivity growth. Investment accelerated even more sharply in the U.K than the U.S. in the second half of the 1990s, so this suspect has a case to answer. We found that disruption costs could account for at most about a third of the measured slowdown.

Given that the most obvious suspects for the U.K. performance seem to have alibis, we take an alternative path. ${ }^{44}$ In particular, we believe that understanding why the U.K. has not yet seen a TFP acceleration

\footnotetext{
${ }^{44}$ In keeping with the mystery theme of this paper, now seems an appropriate time to quote Sherlock Holmes: "[W]hen you have excluded the impossible, whatever remains, however improbable, must be the truth." We are dumbfounded anew by Holmes's genius, since we have never managed to exclude enough impossibles to reduce the improbable-but-true set to a singleton!
} 
requires that we understand why, in fact, the United States did. Our answer emphasizes ICT and the role of complementary investments/innovations induced by it. ICT seems to many observers to be the major locus of innovation in recent decades; but at the same time, we find that most of the measured TFP acceleration took place outside of the production of ICT goods. These two observations are consistent with the predictions of models of ICT as a general purpose technology.

In particular, a pervasive theme of the microeconomic literature on ICT is the need for organizational change if full advantage is to be taken of the new technology. We modeled organizational change as the accumulation of intangible "complementary" capital. This means that the typical firm is also producing a stream of intangible output that constitutes gross investment in complementary capital. Some of this output, such as the production of own-account software, is now explicitly measured in the national accounts, but arguably much is not. To the extent that there is unmeasured output and unmeasured capital, conventional TFP growth will be a biased measure of true technical change. Growth in the complementary capital stock tends to raise measured TFP growth, but growth of complementary investment tends to reduce it, by diverting resources from normal production. During the transition to a new steady state, the net bias can go either way; but the more that the growth rate of complementary investment (unmeasured output) exceeds that of complementary capital (unmeasured input), the more likely is it that measured TFP will be below the true rate of technical change. This GPT view also suggests that current productivity growth may be influenced by the accumulation of complementary capital in earlier periods.

A fundamental difficulty, of course, is that complementary investment and capital are unmeasured. However, theory suggests that observed ICT capital and investment should serve as reasonable proxies. In line with this GPT view, the U.S. industry data suggest that ICT capital growth is associated with industry TFP growth with long (and perhaps variable) lags of 5 to 15 years. Indeed, controlling for past growth in ICT capital, contemporaneous growth in ICT capital is negatively associated with TFP growth in the late 1990s. We find this result encouraging, since to our knowledge no other empirical exercise has connected aggregate and industry-level U.S. TFP performance in the late 1990s either to the persuasive macro models of General Purpose Technologies or to the stimulating micro empirical work that supports the GPT hypothesis.

The results for the U.K. are weaker. But we do find that in the U.K. the rapid growth of ICT investment post 1995, which was higher than the growth of ICT capital, appreciably retarded the measured growth of productivity. Comparing the second with the first half of the 1990s, the change in TFP growth is positively and 
significantly related to the change in ICT capital deepening. But it is significantly and negatively associated with ICT investment growth (the latter weighted by the investment-output ratio). These results are consistent with the notion that U.K. firms were accumulating complementary capital intensively in the late 1990s, in contrast with the U.S. accumulation much earlier. Hence, in this view, the U.K. economy most likely experienced strong underlying TFP growth despite the poor measured figures. But the point estimates suggest that as a whole, ICT investment raised, not lowered, overall TFP growth in the U.K. in the late 1990s-i.e., they do not explain the pervasive TFP slowdown.

The results in this paper are suggestive but, as yet, it is too early to indict complementary capital as the sole culprit in the crime. It is, of course, always a challenge to provide incontrovertible proof of a hypothesis that implies that both inputs and output are unobserved! Nevertheless, several puzzles remain. In particular, if our hypothesis is correct, why did the U.K. invest later in complementary capital than the U.S.? Even granted that they did invest later, why are the coefficients on contemporaneous ICT investment so low?

One hypothesis that we are considering in current research is that there may have been a shortage of skilled, college-educated managers to implement required reorganizations earlier. This hypothesis would suggest that our model (and our empirical specification) is too simple—we need a third factor, skilled labor, to make complementary capital productive or else its accumulation cheaper. Certainly, the evidence that the skills premium has widened in the U.K. (as it did earlier in the U.S.) is potentially consistent with this view. This hypothesis also suggests that on its own, ICT might be an inadequate proxy to fully capture the complementary investments we think are going on.

In addition, although labor and product market regulation generally appear similar, differences in competitive intensity could still play a role. A major contrast between the U.S. and the U.K is in wholesale and retail trade. As we have seen, productivity rose sharply in these industries in the U.S. post-1995 while falling in the U.K. Some (e.g., Lovegrove et al., 1999) have blamed restrictive planning laws in the U.K. which may have hampered the growth of "big box" retailing. But it is not immediately clear why the major U.K. retailers (who also carry out the wholesale function) should invest less in ICT just for this reason: why does a comparatively low store size in a chain of supermarkets inhibit the retail firm from investing in computerised inventory control systems? However, if planning laws reduce competitive intensity by blocking entry, then they may inhibit investment too. At all events, the role of competitive intensity also seems a fruitful topic for future research. 


\section{Bibliography}

Aaronson, D. and D. Sullivan. (2001). Growth in worker quality. Economic Perspectives, Federal Reserve Bank of Chicago, (25:4): 53-74.

Abbade, J. (1999). Inventing the Internet. Cambridge, MA: The MIT Press.

Aghion, P., N. Bloom, R. Blundell, R. Griffith, and P. Howitt. (2002). Competition and innovation: An inverted U relationship. Cambridge, MA: National Bureau of Economic Research. NBER Working Paper 9269.

Baily, M. N. and R. Lawrence. (2001). Do we have a new e-conomy? American Economic Review 91:308-312.

Bakhshi, H., Oulton, N. and J. Thompson. (2003). Modelling investment when relative prices are trending: theory and evidence for the United Kingdom. Bank of England Working Paper 189.

Basu, S. and J. G. Fernald. (2001). Why is productivity procyclical? Why do we care?" In New Developments in Productivity Analysis, edited by C. Hulten, E. Dean, and M. Harper,. Cambridge, MA: National Bureau of Economic Research.

Basu, S., J. G. Fernald, and Matthew D. Shapiro. (2001). Productivity growth in the 1990s: Technology, utilization, or adjustment? Carnegie-Rochester Conference Series on Public Policy 55:117-165.

Basu, S. and M. Kimball. (1997). Cyclical Productivity with unobserved input variation. Cambridge, MA: National Bureau of Economic Research. NBER Working Paper 5915 (December).

Bean, C. and Crafts, N. (1996). British economic growth since 1945: relative economics decline ... and renaissance? In Economic growth in Europe since 1945, edited by N. Crafts and G. Toniolo, Cambridge, New York and Melbourne: Cambridge University Press.

Belsley, D., E. Kuh, and R. Welsch. (1980). Regression Diagnostics: Identifying Influential Data and Sources of Collinearity. New York: John Wiley and Sons.

Berners-Lee, T. (1999). Weaving the Web: The Past, Present and Future of the World Wide Web by Its Inventor (with M. Fischetti). London: Orion Business Books.

Bessen, J. (2003). Technology adoption costs and productivity growth: The transition to information technology. Manuscript.

Bosworth, B. P. and J. E. Triplett. (2002). 'Baumol's Disease' has been cured: IT and multifactor productivity in U.S. services industries. Manuscript, Brookings Institution.

Bresnahan, T. F. (undated). The mechanisms of information technology's contribution to economic growth. Prepared for presentation at the Saint-Gobain Centre for Economic Research.

Bresnahan, T. F. and M. Trajtenberg. (1995). General purpose technologies: 'Engines of growth?' Journal of Econometrics 65(Special Issue, January):83-108.

Brookings Institution. (2002). Workshop on economic measurement service industry productivity: New estimates and new problems, May 17, 2002. Summary of the Workshop.

http://www.brook.edu/es/research/projects/ productivity/workshops/20020517_summary.pdf (Downloaded March 16, 2003). 
Brynjolfsson, E. and L. M. Hitt. (2000). Beyond computation: Information technology, organizational transformation and business performance. Journal of Economic Perspectives 14(4):23-48.

Brynjolfsson, E. and L. M. Hitt. (2002). Computing productivity: Firm-level evidence, MIT Working Paper 4210-01 (Web site draft revised November 2002).

Brynjolfsson, E. and S. Yang. (2001). Intangible assets and growth accounting: Evidence from computer investments. Manuscript.

Burriel-Llombart, P. and J. Jones. (2003). A quality-adjusted labour input series for the UK (1975-2002). Bank of England Working Paper, forthcoming.

Caselli, F. (1999). Technological revolutions. American Economic Review 89(March).

Chandler, A. D. Jr. (1977). The Visible Hand. Cambridge: Harvard University Press.

Card, D. and R. B. Freeman. (2001). What have two decades of British economic reform delivered? Cambridge, MA: National Bureau of Economic Research. NBER Working Paper 8801.

Colecchia, A and P. Schreyer. (2002). ICT investment and economic growth in the 1990s: is the United States a unique case? A comparative study of nine OECD countries. Review of Economic Dynamics 5(2):40842.

Council of Economic Advisors. (2001). Annual report of the Council of Economic Advisors. In the Economic Report of the President, January.

Council of Economic Advisors. (2003). Annual report of the Council of Economic Advisors. In the Economic Report of the President, February.

Crafts, N. and M. O’Mahony. (2001). A perspective on UK productivity performance." Fiscal Studies 22 3:271-306.

Daveri, F. (2002). The new economy in Europe. Oxford Review of Economic Policy 18(Autumn): 345-362.

David, P. A. and G. Wright. (1999). General purpose technologies and surges in productivity: Historical reflections on the future of the ICT revolution. Manuscript.

De Long, J. B. (2002). Productivity Growth in the 2000s. Paper presented at NBER Macroeconomics Annual Conference. Cambridge, MA, April.

Feldstein, M. (2001). Comments \& analysis. In The Financial Times, June 28.

Foster, L., J. Haltiwanger, and C.J. Krizan. (2002). The link between aggregate and micro productivity growth: Evidence from retail trade. Cambridge, MA: National Bureau of Economic Research. NBER Working Paper 9120.

Gordon, R. (2003). High tech innovation and productivity growth: does supply create its own demand? Cambridge, MA: National Bureau of Economic Research. NBER Working Paper w9437.

Greenspan, A. (2000). Technology and the Economy. Speech before the Economic Club of New York, January 13. Available at www.federalreserve.gov/boarddocs/speeches/2000. 
Greenwood, J., Hercowitz Z., and P. Krusell. (1997). Long run implications of investment-specific technological change. American Economic Review 87:342-362.

Greenwood, J. and M. Yorokoglu. (1997). 1974. Carnegie-Rochester Conference Series on Public Policy 46:4995.

Griliches, Z. (1994). Productivity, R\&D, and the data constraint. American Economic Review 84(1):1-23.

Grimm, B. T., Moulton, B. R., and D. B. Wasshausen. (2002). Information processing equipment and software in the national accounts. Paper prepared for the NBER/CRIW Conference on Measuring Capital in the New Economy, April 26-27, 2002, Federal Reserve Board, Washington, D.C. Available from www.bea.gov.

Gust, C. and J. Marquez. (2000). Productivity developments abroad. Federal Reserve Bulletin, 86(10): 665-81.

Gust, C. and J. Marquez. (2002). International Comparisons of Productivity Growth: The Role of Information Technology and Regulatory Practices. Labour Economics Special Issue on Productivity edited by Gilles Saint-Paul, forthcoming.

Hall, R. E. (2001). The stock market and capital accumulation. American Economic Review 91(December):1185-1202.

Helpman, E. (ed). (1998). General Purpose Technologies and Economic Growth. Cambridge: MIT Press, 1998.

Helpman, E. and M. Trajtenberg. (1998). Diffusion of general purpose technologies. In General Purpose Technologies and Economic Growth, edited by E. Helpman. Cambridge: MIT Press.

Hobijn, B. and B. Jovanovic. (2001). The information-technology revolution and the stock market: evidence. American Economic Review 91(December):1203-1220.

Hornstein, A. and P. Krusell. (1996). Can technology improvements cause productivity slowdowns? In NBER Macroeconomics Annual edited by Bernanke and Rotemberg. Cambridge, MA: National Bureau of Economic Research.

Howitt, P. (1998). Measurement, obsolescence, and general purpose technologies. In General purpose technologies and economic growth, edited by E. Helpman. Cambridge and London: MIT Press.

Hulten, C. R. (1996). Quality change in capital goods and its impact on economic growth. Cambridge, MA: National Bureau of Economic Research . National Bureau of Economic Research Working Paper 5569.

Jones, C. (1995). R\&D-based models of economic growth. Journal of Political Economy, 103(August):759-784.

Jorgenson, D. W. (2001). Information technology and the U.S. economy. American Economic Review 91(March): 1-32.

Jorgenson, D. W., Ho, M. S., and K. J. Stiroh. (2002). Growth of U.S. industries and investments in information technology and higher education. Manuscript, October 7, 2002.

Jorgenson, D. W., and K. J. Stiroh. (2000). Raising the speed limit: U.S. economic growth in the information age. Brookings Papers on Economic Activity 1:125-211.

Jovanovic, B. and P. L. Rousseau. (2003). Mergers as Reallocation. Unpublished, NYU, February. 
Krueger, D. and K. Kumar. (2003). US-Europe differences in technology adoption and growth: The role of education and other policies. Manuscript prepared for the Carnegie-Rochester Conference, April 2003.

Krusell, P., Ohanian, L., Rios-Rull, J., and Gianluca Violante. (2000). Capital-skill complementarity and Inequality: A Macroeconomic analysis. Econometrica 68(September):1029-54

Laitner, J. and D. Stolyarov. (2001). Technological change and the stock market. Manuscript, University of Michigan.

Lequiller, F. (2001). The new economy and the measurement of GDP growth. INSEE Working Paper G 2001 / 01. Paris.

Lovegrove, N. C., Fidler, S., Harris, V. J., Mullings, H. M., Lewis, W. W., and S. D. Anthony. (1999). Why is labor productivity in the United Kingdom so low? The McKinsey Quarterly anthologies. McKinsey Global Institute.

Lynch, L. and S. Nickell. (2001). Rising productivity and falling unemployment: can the US experience be sustained and replicated?" In The Roaring Nineties, edited by A. Krueger and R. Solow. New York: Russell Sage Foundation.

McKinsey Global Institute. (2001). US productivity growth 1995-2000: Understanding the contribution of information technology relative to other factors. Washington, D.C.: McKinsey Global Institute. October.

Nickell, S. (1996). Competition and corporate performance. Journal of Political Economy 104:724-46.

Nickell, S. and G. Quintini. (2001). The recent performance of the UK labour market. Talk given to the Economic Section of the British Association for the Advancement of Science, $4^{\text {th }}$ September, in Glasgow. Available from www.bankofengland.co.uk.

Nordhaus, W.D. (2002). Productivity Growth and the New Economy. Brookings Papers on Economic Activity 2.

O’Mahony, M. and de Boer, W. (2002). Britain's relative productivity performance: updates to 1999. Final report to DTI/Treasury/ONS. Available at www.niesr.ac.uk.

Oliner, S.D. and D E. Sichel. (2000). The resurgence of growth in the late 1990s: Is information technology the story? Journal of Economic Perspectives 14(Fall):3-22.

Oliner, S.D. and D E. Sichel. (2002). Information technology and productivity: Where are we now and where are we going? Economic Review, Federal Reserve Bank of Atlanta 87(3):15-44.

Oulton, N. (1995). Supply side reform and UK economic growth: what happened to the miracle? National Institute Economic Review 154(November):53-70.

Oulton, N. (2001a). Must the growth rate decline? Baumol's unbalanced growth revisited. Oxford Economic Papers 53:605-627.

Oulton, N. (2001b). ICT and productivity growth in the UK. Bank of England Working Paper 140. Available at www.bankofengland.co.uk.

Oulton, N. (2002). ICT and productivity growth in the UK. Oxford Review of Economic Policy 18(3):363-379. 
Oulton, N. and S. Srinivasan. (2003). Capital stocks, capital services and depreciation: an integrated framework. Bank of England Working Paper 192. Available at www.bankofengland.co.uk.

Parker, R. and B. Grimm. (2000). Recognition of business and government expenditures for software as investment: methodology and quantitative impacts, 1959-98. Washington, DC: Bureau of Economic Analysis. Available at www.bea.doc.gov.

Schreyer, P. (2000). The contribution of information and communication technology to output growth: a study of the G7 countries. Paris: OECD. STI Working Papers 2000/2.

Schreyer, P. (2002). Computer price indices and international growth and productivity comparisons. Review of Income and Wealth 48(March):15-31.

Shapiro, M. (1986). The dynamic demand for capital and labor. Quarterly Journal of Economics

Stiroh, K. J. (2002a). Are ICT spillovers driving the New Economy? Review of Income and Wealth 48(1):33-58.

Stiroh, K. J. (2002b). Information technology and the U.S. productivity revival: what do the industry data say? American Economic Review 92(5):1559-1576.

Tevlin, S. and Whelan, K. (2000). Explaining the Investment Boom of the 1990s. Journal of Money, Credit and Banking (forthcoming).

van Ark, B., Melka, J., Mulder, N., Timmer, M., and G. Ypma. (2002). ICT investment and growth accounts for the European Union, 1980-2000. Final Report on ICT and growth accounting for the DG Economics and Finance of the European Commission, Brussels. Downloaded from http://www.eco.rug.nl/GGDC/dseries/Data/ICT/euictgrowth.pdf.

Wolff, E. N. (2002). Productivity, Computerization, and Skill Change. Cambridge, MA: National Bureau of Economic Research. National Bureau of Economic Research Working Paper 8743. 
TABLE 1

MACRO PERFORMANCE: U.S. VS. U.K.

(annual percent change)

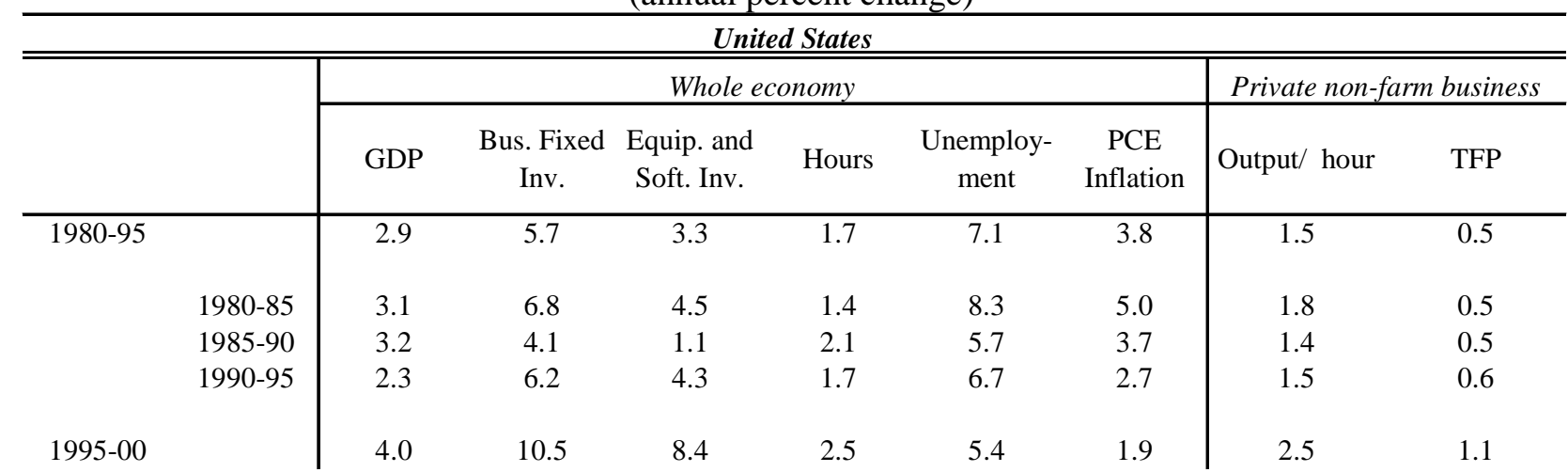

\begin{tabular}{|c|c|c|c|c|c|c|c|c|c|}
\hline \multicolumn{10}{|c|}{ United Kingdom } \\
\hline & & \multicolumn{6}{|c|}{ Whole economy } & \multicolumn{2}{|c|}{ Private non-farm business } \\
\hline & & GDP & $\begin{array}{l}\text { Bus. Fixed } \\
\text { Inv. }\end{array}$ & $\begin{array}{l}\text { Equip. and } \\
\text { Soft. Inv. }\end{array}$ & Hours & $\begin{array}{l}\text { Unemploy- } \\
\text { ment }\end{array}$ & $\begin{array}{c}\text { RPIX } \\
\text { Inflation }\end{array}$ & Output/ hour & TFP \\
\hline $1980-95$ & & 2.5 & 3.1 & 3.7 & 0.0 & 9.9 & 5.4 & 3.4 & 1.2 \\
\hline & $1980-85$ & 2.1 & 3.2 & 3.9 & -0.3 & 11.1 & 7.1 & 3.5 & 1.4 \\
\hline & $1985-90$ & 3.1 & 7.0 & 6.5 & 2.0 & 9.0 & 5.2 & 2.6 & 0.6 \\
\hline & $1990-95$ & 1.8 & -0.8 & 1.1 & -1.5 & 9.5 & 3.9 & 3.9 & 1.7 \\
\hline 1995-00 & & 2.8 & 6.4 & 10.0 & 0.8 & 6.7 & 2.5 & 2.9 & 0.8 \\
\hline
\end{tabular}

Sources: U.S.: GDP, business fixed investment, equipment and software investment, and PCE inflation are from Bureau of Economic Analysis and (except for business fixed investment) refer to whole-economy averages. Unemployment rates are from Bureau of Labor Statistics and are averages over the respective periods. Hours, output per hour, and TFP are from the Bureau of Labor Statistics multifactor productivity dataset, and cover the private nonfarm business sector. TFP incorporates an adjustment for labor quality.

U.K.: Output, business fixed investment, hours, unemployment, and inflation are from the Office of National Statistics and (except for business fixed investment) refer to whole-economy averages. Equipment and software investment is from the Office of National Statistics and Oulton and Srinivasan (2003). Output per hour and TFP are derived from the UK dataset constructed for this paper and cover the private nonfarm business sector. While the hours data match the aggregate, the output data differ from the National Accounts because of adjustments to ICT investment in each industry and the output of the financial services industry. TFP incorporates an adjustment for labor quality. 
TABLE 4

U.S.: TOTAL FACTOR Productivity Growth By INDUSTRY In PRIVATE NON-FARM BuSINESS, 1990-2000

(percent change, annual rate)

\begin{tabular}{|c|c|c|c|c|c|c|c|}
\hline & \multicolumn{3}{|c|}{ Productivity (Gross Output terms) ${ }^{2}$} & \multicolumn{3}{|c|}{ Productivity (Value - Added terms) ${ }^{3}$} & \multirow{2}{*}{$\begin{array}{c}\text { Share of Nominal } \\
\text { Value Added }\end{array}$} \\
\hline & pre-1995 & post-1995 & Acceleration & pre-1995 & post-1995 & Acceleration & \\
\hline $\begin{array}{l}\text { Private Non-Farm Economy } \\
\text { (adjusted for labor quality) }{ }^{1}\end{array}$ & 0.30 & 0.98 & 0.68 & 0.59 & 1.92 & 1.32 & 100.0 \\
\hline contribution of labor quality & 0.16 & 0.09 & -0.08 & 0.32 & 0.16 & & \\
\hline $\begin{array}{l}\text { Private Non-Farm Economy } \\
\text { (NOT adjusted for labor quality) }\end{array}$ & 0.47 & 1.06 & 0.60 & 0.91 & 2.08 & 1.17 & \\
\hline Mining & 1.61 & -1.16 & -2.77 & 3.08 & -2.15 & -5.23 & 1.6 \\
\hline Manufacturing & 0.86 & 0.97 & 0.11 & 2.40 & 2.76 & 0.36 & 20.6 \\
\hline Nondurables & 0.34 & -0.39 & -0.73 & 1.02 & -1.20 & -2.22 & 8.7 \\
\hline Durables & 1.34 & 2.08 & 0.74 & 3.47 & 5.61 & 2.14 & 12.0 \\
\hline Construction & 0.22 & -0.58 & -0.80 & 0.39 & -0.98 & -1.38 & 6.1 \\
\hline Transportation & 0.83 & 0.77 & -0.06 & 1.69 & 1.53 & -0.16 & 4.2 \\
\hline Communication & 1.47 & 0.01 & -1.46 & 2.31 & 0.15 & -2.16 & 3.7 \\
\hline Electric/Gas/Sanitary & 0.27 & 0.11 & -0.16 & 0.42 & 0.17 & -0.25 & 2.9 \\
\hline Wholesale Trade & 1.08 & 3.39 & 2.32 & 1.66 & 5.37 & 3.71 & 9.2 \\
\hline Retail Trade & 0.49 & 3.23 & 2.74 & 0.83 & 5.33 & 4.50 & 11.8 \\
\hline Finance \& Insurance & 0.24 & 1.95 & 1.72 & 0.44 & 3.39 & 2.96 & 10.7 \\
\hline Finance & 0.86 & 2.96 & 2.10 & 1.31 & 4.90 & 3.59 & 7.5 \\
\hline Insurance & -0.81 & 0.05 & 0.86 & -1.49 & -0.06 & 1.44 & 3.2 \\
\hline Business Servs. \& Real Est. & 0.68 & 0.24 & -0.45 & 1.12 & 0.40 & -0.72 & 13.9 \\
\hline Business Services & 0.41 & -0.89 & -1.30 & 0.60 & -1.40 & -2.00 & 7.1 \\
\hline Real Estate & 0.87 & 1.27 & 0.40 & 1.55 & 2.34 & 0.79 & 6.8 \\
\hline Other Services & -1.19 & 0.05 & 1.24 & -1.89 & 0.08 & 1.97 & 15.2 \\
\hline ICT $_{\text {producing }}{ }^{4}$ & 2.41 & 4.43 & 2.02 & 5.52 & 11.02 & 5.50 & 5.3 \\
\hline Non ICT producing & 0.32 & 0.80 & 0.48 & 0.61 & 1.54 & 0.93 & 94.7 \\
\hline Well Measured Ind. ${ }^{5}$ & 0.82 & 1.44 & 0.62 & 1.80 & 3.17 & 1.37 & 54.2 \\
\hline Well Measured (excluding ICT producing) & 0.62 & 1.04 & 0.42 & 1.35 & 2.24 & 0.88 & 48.9 \\
\hline
\end{tabular}

1. For productivity purposes, our definition of private non-farm business excludes holding and other investment offices along with miscellaneous services, since consistent input and output data are unavailable for these industries.

2. A sector's gross-output TFP growth is calculated as a weighted average of the industry-level gross-output TFP growth rates; the weight for each industry is the ratio of its Domar weight to the sum of the Domar weights for that sector.

3. Value-added TFP growth is defined as (gross output TFP growth)/(1-share of intermediate inputs). Implicitly, this uses the Tornquist index of value added for a sector

4. For the US: ICT-producing includes industrial machinery and electronic and other electrical equipment sectors.

5. US and UK: Well-measured industries include mining, manufacturing, transportation, communication, electric et al., and wholesale and retail trade. 
TABLE 5

U.K.: Total FACTOR ProduCtivity GroWTh BY INDUSTRY IN PRIVATE NON-FARM BUSINESS, 1990-2000

(percent change, annual rate)

\begin{tabular}{|c|c|c|c|c|c|c|c|}
\hline & \multicolumn{3}{|c|}{ Productivity (Gross Output terms) ${ }^{1}$} & \multicolumn{3}{|c|}{ Productivity (Value - Added terms) ${ }^{2}$} & \multirow{2}{*}{$\begin{array}{c}\begin{array}{c}\text { Share of Nominal } \\
\text { Value Added }\end{array} \\
(2000)\end{array}$} \\
\hline & $1990-1995$ & $1995-2000$ & Acceleration & $1990-1995$ & $1995-2000$ & Acceleration & \\
\hline $\begin{array}{l}\text { Private Non-Farm Economy with Quality } \\
\text { adjusted labor input }\end{array}$ & 0.79 & 0.35 & -0.44 & 1.72 & 0.78 & -0.94 & 100.0 \\
\hline Labor quality adjustment & 0.39 & 0.21 & -0.18 & 0.84 & 0.48 & -0.37 & \\
\hline $\begin{array}{l}\text { Private Non-Farm Economy with Non-Quality } \\
\text { adjusted labor input }\end{array}$ & 1.18 & 0.56 & -0.62 & 2.56 & 1.25 & -1.31 & 100.0 \\
\hline Mining & 5.69 & 0.89 & -4.79 & 9.20 & 1.34 & -7.86 & 3.8 \\
\hline Manufacturing & 1.11 & 0.51 & -0.59 & 3.03 & 1.42 & -1.61 & 23.2 \\
\hline Nondurables & 1.04 & -0.03 & -1.07 & 2.81 & -0.07 & -2.89 & 15.7 \\
\hline Durables & 1.26 & 1.57 & 0.31 & 3.52 & 4.57 & 1.05 & 7.5 \\
\hline Construction & 0.67 & -0.31 & -0.98 & 1.77 & -0.84 & -2.61 & 6.6 \\
\hline Transportation & 1.62 & 0.50 & -1.12 & 3.46 & 1.18 & -2.28 & 6.5 \\
\hline Communication & 3.26 & 2.61 & -0.65 & 4.83 & 4.77 & -0.06 & 3.9 \\
\hline Electric/Gas/Sanitary & 1.22 & 0.99 & -0.24 & 3.11 & 2.61 & -0.50 & 3.1 \\
\hline Wholesale Trade & 2.22 & 2.13 & -0.09 & 3.44 & 3.71 & 0.28 & 6.8 \\
\hline Retail Trade & 0.38 & -0.58 & -0.96 & 0.73 & -1.17 & -1.90 & 13.0 \\
\hline $\begin{array}{l}\text { Finance and Insurance } \\
\qquad \begin{array}{l}\text { Finance } \\
\text { Insurance }\end{array}\end{array}$ & 0.90 & 1.56 & 0.66 & 1.89 & 3.87 & 1.98 & 6.2 \\
\hline $\begin{array}{c}\text { Business Services and Real Estate } \\
\text { Business Services } \\
\text { Real Estate }\end{array}$ & 0.64 & 0.53 & -0.11 & 1.13 & 0.99 & -0.14 & 21.0 \\
\hline Other Services & 1.06 & 0.10 & -0.96 & 2.05 & 0.19 & -1.86 & 5.7 \\
\hline ICT producing $^{3}$ & 1.45 & 3.75 & 2.30 & 3.82 & 10.46 & 6.64 & 3.3 \\
\hline Non ICT producing & 1.16 & 0.41 & -0.75 & 2.52 & 0.93 & -1.59 & 96.7 \\
\hline Well Measured Ind. ${ }^{4}$ & 1.38 & 0.59 & -0.79 & 3.10 & 1.37 & -1.73 & 60.5 \\
\hline Well Measured (excluding ICT producing) & 1.37 & 0.37 & -1.00 & 3.90 & 0.45 & -3.45 & 57.2 \\
\hline
\end{tabular}

1. A sector's gross-output TFP growth is calculated as a weighted average of the industry-level gross-output TFP growth rates; the weight for each industry is the ratio of its Domar weight to the sum of the Domar weights for that sector.

2. Value-added productivity growth equals (gross output productivity growth)/(1-share of intermediate inputs)

3. For the UK: ICT-producing comprises electrical engineering and electronics (SIC92 30-33)

4. For the UK: Well-measured industries comprise mining, manufacturing, transportation, communication, electricity, water and gas supply, wholesale, retail trade and waste treatment 
TABLE 6

U.S. : COMPUTER, SOFTWARE, AND COMMUNICATION SHARES OF VALUE - ADDED REVENUE (percent)

\begin{tabular}{|c|c|c|c|c|c|c|c|c|}
\hline & \multicolumn{4}{|c|}{1990} & \multicolumn{4}{|c|}{2000} \\
\hline & Computer & Software & Communication & Total ICT & Computer & Software & Communication & Total ICT \\
\hline Private Non-Farm Economy & 1.35 & 1.24 & 1.70 & 4.29 & 1.60 & 2.31 & 1.59 & 5.50 \\
\hline Mining & 0.18 & 0.15 & 0.32 & 0.65 & 0.27 & 0.36 & 0.13 & 0.77 \\
\hline Manufacturing & 1.09 & 0.94 & 0.56 & 2.59 & 1.32 & 1.81 & 0.61 & 3.74 \\
\hline Nondurables & 0.76 & 0.66 & 0.31 & 1.73 & 1.00 & 1.37 & 0.53 & 2.89 \\
\hline Durables & 1.48 & 1.26 & 0.84 & 3.58 & 1.74 & 2.32 & 0.71 & 4.77 \\
\hline Construction & 0.42 & 0.37 & 0.12 & 0.91 & 2.89 & 4.01 & 1.19 & 8.09 \\
\hline Transportation & 0.16 & 0.14 & 1.52 & 1.82 & 0.64 & 0.87 & 2.44 & 3.95 \\
\hline Communication & 1.23 & 1.09 & 30.51 & 32.83 & 1.70 & 2.51 & 24.81 & 29.01 \\
\hline Electric/Gas/Sanitary & 1.33 & 1.14 & 3.18 & 5.65 & 1.25 & 1.66 & 3.10 & 6.01 \\
\hline Wholesale Trade & 2.78 & 2.48 & 0.87 & 6.12 & 4.37 & 5.34 & 1.19 & 10.91 \\
\hline Retail Trade & 1.03 & 0.85 & 0.20 & 2.08 & 1.04 & 1.35 & 0.31 & 2.69 \\
\hline Finance \& Insurance & 3.35 & 3.56 & 1.16 & 8.06 & 2.60 & 5.22 & 0.87 & 8.69 \\
\hline Finance & 3.90 & 4.16 & 1.38 & 9.44 & 3.01 & 6.09 & 0.98 & 10.08 \\
\hline Insurance & 1.97 & 2.06 & 0.59 & 4.62 & 1.55 & 2.99 & 0.61 & 5.15 \\
\hline Business Servs. \& Real Est. & 1.98 & 1.86 & 0.64 & 4.48 & 1.87 & 2.08 & 0.47 & 4.43 \\
\hline Business Services & 4.75 & 4.48 & 0.95 & 10.17 & 3.44 & 3.82 & 0.70 & 7.96 \\
\hline Real Estate & 0.05 & 0.04 & 0.42 & 0.50 & 0.13 & 0.14 & 0.23 & 0.49 \\
\hline Other Services & 0.69 & 0.62 & 0.25 & 1.56 & 0.67 & 1.23 & 0.27 & 2.16 \\
\hline ICT producing $^{1}$ & 1.84 & 1.57 & 1.39 & 4.80 & 2.49 & 3.29 & 0.83 & 6.60 \\
\hline Non ICT producing & 1.32 & 1.23 & 1.73 & 4.28 & 1.56 & 2.27 & 1.64 & 5.47 \\
\hline $\begin{array}{l}\text { Well Measured Ind. }{ }^{2} \\
\text { Well Measured (excluding }\end{array}$ & 1.15 & 0.99 & 2.39 & 4.53 & 1.58 & 2.06 & 2.41 & 6.06 \\
\hline ICT producing) & 1.08 & 0.94 & 2.53 & 4.55 & 1.51 & 1.96 & 2.59 & 6.06 \\
\hline
\end{tabular}

1. For the US: ICT-producing includes industrial machinery and electronic and other electrical equipment sectors.

2. US and UK: Well-measured industries include mining, manufacturing, transportation, communication, electric et al., and wholesale and retail trade.

Note: "Holding and other Investment Offices" data were included in finance, and other services contains more services than had been previously defined for our calculations of productivity.

Source: Author's calculations using payments to ICT capital from BLS and nominal value added from BEA. 
TABLE 7

U.K. : COMPUTER, SOFTWARE, AND COMMUNICATION SHARES OF VALUE - ADDED REVENUE (percent)

\begin{tabular}{|c|c|c|c|c|c|c|c|c|}
\hline & \multicolumn{4}{|c|}{1990} & \multicolumn{4}{|c|}{2000} \\
\hline & Computer & Software & Communication & Total ICT & Computer & Software & Communication & Total ICT \\
\hline Private Non-Farm Economy & 1.97 & 1.58 & 0.75 & 4.30 & 2.82 & 2.59 & 0.85 & 6.26 \\
\hline Mining & 0.04 & 0.11 & 0.22 & 0.37 & 0.02 & 0.22 & 0.11 & 0.35 \\
\hline Manufacturing & 0.68 & 1.08 & 0.29 & 2.05 & 1.74 & 1.25 & 0.29 & 3.28 \\
\hline Nondurables & 0.53 & 0.97 & 0.47 & 1.98 & 2.41 & 1.55 & 0.68 & 4.64 \\
\hline Durables & 0.75 & 1.13 & 0.20 & 2.08 & 1.41 & 1.11 & 0.11 & 2.62 \\
\hline Construction & 0.31 & 2.85 & 0.49 & 3.65 & 0.41 & 3.11 & 0.26 & 3.78 \\
\hline Transportation & 0.35 & 0.35 & 0.02 & 0.73 & 1.10 & 1.32 & 0.02 & 2.44 \\
\hline Communication & 1.12 & 0.22 & 6.85 & 8.19 & 5.51 & 2.03 & 10.72 & 18.26 \\
\hline Electric/Gas/Sanitary & 0.78 & 0.65 & 0.83 & 2.25 & 1.34 & 1.10 & 0.86 & 3.30 \\
\hline Wholesale Trade & 2.99 & 1.55 & 0.89 & 5.43 & 4.74 & 4.12 & 0.55 & 9.40 \\
\hline Retail Trade & 1.03 & 0.95 & 1.28 & 3.26 & 1.21 & 1.46 & 0.55 & 3.22 \\
\hline $\begin{array}{l}\text { Finance and Insurance } \\
\qquad \begin{array}{r}\text { Finance } \\
\text { Insurance }\end{array}\end{array}$ & 5.51 & 5.90 & 0.05 & 11.46 & 4.75 & 8.53 & 0.09 & 13.37 \\
\hline $\begin{array}{l}\text { Business Services and Real Estate } \\
\text { Business Services } \\
\text { Real Estate }\end{array}$ & 6.13 & 1.84 & 0.39 & 8.37 & 5.70 & 3.74 & 0.58 & 10.02 \\
\hline Other Services & 1.55 & 1.20 & 1.37 & 4.12 & 1.58 & 1.88 & 1.16 & 4.61 \\
\hline ICT producing & 0.81 & 1.87 & 1.21 & 3.88 & 2.79 & 2.61 & 0.83 & 6.23 \\
\hline Non ICT producing & 1.49 & 1.25 & 0.60 & 3.34 & 2.74 & 2.57 & 0.82 & 6.13 \\
\hline Well Measured Ind. & 0.91 & 0.90 & 0.90 & 2.71 & 2.00 & 1.59 & 1.05 & 4.64 \\
\hline $\begin{array}{l}\text { Well Measured (excluding ICT } \\
\text { producing) }\end{array}$ & 0.92 & 0.84 & 0.88 & $2.64 \mid$ & 1.90 & 1.55 & 1.03 & 4.48 \\
\hline
\end{tabular}

1. For the UK: ICT-producing comprises electrical engineering and electronics (SIC92 30-33)

2. For the UK: Well-measured industries comprise mining, manufacturing, transportation, communication, electricity, water and gas supply, wholesale, retail trade and waste treatment. 
TABLE 8

ICT REGRESSIONS WITH CURRENT AND LAGGED ICT CAPITAL GROWTH

Using $\tilde{k}=\mathbf{s}_{\mathrm{K}} \Delta \ln k$ as right-hand regressor, with computers and software as measure of capital

\begin{tabular}{lcc}
\hline & United States & United Kingdom \\
\hline $\mathrm{C}$ & -0.001 & -0.09 \\
& $(0.003)$ & $(0.48)$ \\
$\tilde{k}_{1980-1990}$ & 4.1 & 1.39 \\
$\tilde{k}_{1990-1995}$ & $(7.2)$ & $(3.56)$ \\
$\tilde{k}_{1995-2000}$ & 17.4 & 0.65 \\
& $(5.7)$ & $(2.80)$ \\
Poorly* $\mathrm{C}$ & -8.9 & 0.65 \\
& $(4.8)$ & $(1.48)$ \\
Poorly* $\tilde{k}_{1980-1990}$ & 0.011 & -0.18 \\
& $(0.0058)$ & $(0.48)$ \\
Poorly* $\tilde{k}_{1990-1995}$ & 15.3 & 2.77 \\
& $(7.7)$ & $(3.56)$ \\
Poorly* $\tilde{k}_{1995-2000}$ & -8.1 & -1.60 \\
& $(6.6)$ & $(2.80)$ \\
R2 & -10.1 & -2.60 \\
Observations & $(5.8)$ & $(1.48)$ \\
\hline
\end{tabular}

Robust standard errors in parentheses. We omit ICT-producing industries (this has relatively little effect on coefficients).

TABLE 9

INVESTMENT-ACCELERATION FORM OF ICT REGRESSION

\begin{tabular}{|l|l|l|}
\hline & United States & United Kingdom \\
\hline$\left(\tilde{k}_{i, 1995-2000}-\tilde{k}_{i, 1990-1995}\right)$ & 0.21 & 4.41 \\
& $(2.27)$ & $(1.02)$ \\
\hline$\left(\tilde{i}_{i, 1995-2000}-\tilde{i}_{i, 1990-1995}\right)$ & -0.04 & -1.63 \\
\hline $\mathrm{R}^{2}$ & $(0.75)$ & $(0.41)$ \\
\hline Observations & 0.01 & 0.41 \\
\hline
\end{tabular}

Robust standard errors in parenthesis. Constant term not shown. We omit ICT-producing industries (this has relatively little effect on coefficients). 
Figure 1.

Capital Share TIMes CaPITAL gRoWTH
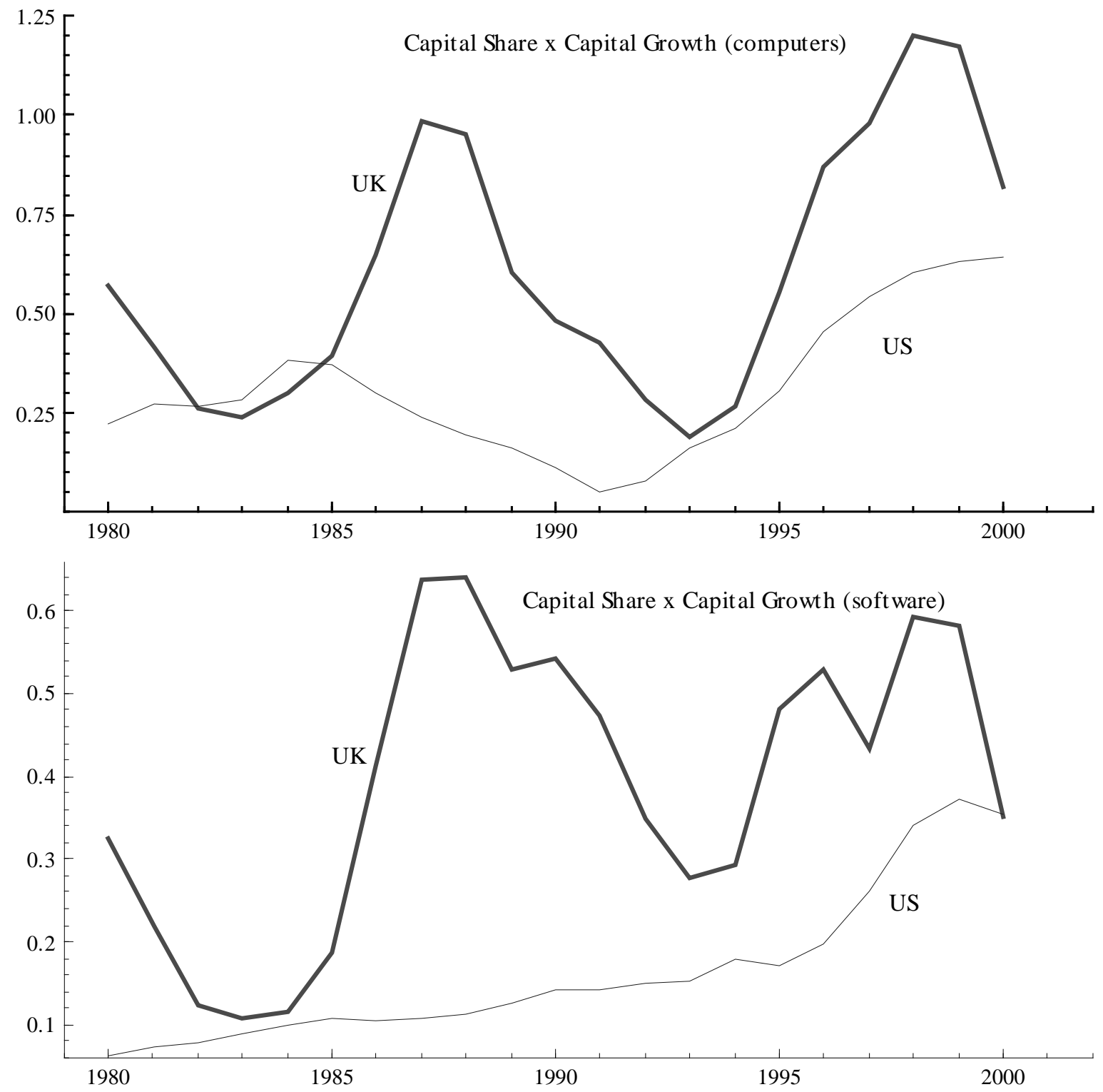